\title{
Coupled and Uncoupled Gating and Desensitization Effects by Pore Domain Mutations in GABA Receptors
}

\author{
Michaela Scheller ${ }^{1}$ and Stuart A. Forman ${ }^{2}$ \\ ${ }_{1}^{1}$ Klinik fuer Anaesthesiologie der Technischen Universitaet Muenchen, Klinikum rechts der Isar, D-81675 Munich, Germany, and \\ 2Department of Anesthesia and Critical Care, Massachusetts General Hospital, Boston, Massachusetts 02114
}

\begin{abstract}
$\mathrm{GABA}_{\mathrm{A}}$ receptors are allosteric ligand-gated ion channels. Agonist-induced gating and desensitization have been proposed to be coupled via pore domain structures. Mutations at two $\alpha_{1}$ subunit pore-domain (transmembrane domain 2) residues enhance GABA sensitivity, leucine-to-threonine at position $264\left(9^{\prime}\right)$, and serine-to-isoleucine at position $270\left(15^{\prime}\right)$. We investigated the role of these residues in gating, desensitization, and deactivation of $\alpha_{1} \beta_{2} \gamma_{2 \mathrm{~L}} \mathrm{GABA}_{\mathrm{A}}$ receptors using rapid GABA concentration jumps and patch-clamp electrophysiology. GABA EC $E_{50}$ values for $\alpha_{1}$ (L264T) $\beta_{2} \gamma_{2 \mathrm{~L}}$ and $\alpha_{1}(\mathrm{~S} 270 \mathrm{I}) \beta_{2} \gamma_{2 \mathrm{~L}}$ currents were, respectively, $\sim 80$-fold and 13 -fold lower than the wild-type $\mathrm{EC}_{50}$. Unlike wild type, both mutant receptors displayed significant picrotoxin-sensitive currents in the absence of GABA, indicating that they enhance gating efficacy. Both mutants displayed current activation rates that matched wild type at $1 \mu \mathrm{m}$ GABA and above. Desensitization of wild-type and $\alpha_{1}(\mathrm{~S} 270 \mathrm{I}) \beta_{2} \gamma_{2 \mathrm{~L}}$ currents displayed indistinguishable rates
\end{abstract}

$\mathrm{GABA}_{\mathrm{A}}$ receptors $\left(\mathrm{GABA}_{\mathrm{A}} \mathrm{Rs}\right)$ are the major inhibitory neurotransmitter receptors in the mammalian CNS and targets for sedatives, anxiolytics, anti-epileptics, and general anesthetics. $\mathrm{GABA}_{\mathrm{A}}$ receptors are pentameric ligand-gated ion channels, part of the superfamily, including nicotinic acetylcholine (nACh), 5-hydroxytryptamine type $3\left(5-\mathrm{HT}_{3}\right)$, and glycine receptors (Ortells and Lunt, 1995). Each homologous $\mathrm{GABA}_{\mathrm{A}}$ receptor subunit contains a large extracellular $\mathrm{N}$-terminal domain and four hydrophobic domains predicted to form transmembrane elements (TM1 to TM4) (Barnard et al., 1998). The chloride-conducting pore of the receptor is thought to be surrounded by predominantly helical TM2 domains (Karlin and Akabas, 1995). Mutations in TM2 domains can affect chloride conductance, sensitivity to blockers, and channel gating (Gurley et al., 1995).

In voltage-clamp recordings of multiple $\mathrm{GABA}_{\mathrm{A}}$ channels, rapid $\mathrm{GABA}$ application activates a chloride current and initiates multiphasic current desensitization to nonconducting states. Both gating and desensitization of ligand-gated receptors display allosterism; they occur with low probability in the absence of agonists

Received March 26, 2002; revised July 17, 2002; accepted July 22, 2002.

This work was supported by a grant from the Max Kade Foundation (M.S.) and National Institutes of Health Grant P01-GM58448 (S.A.F.). We thank Carol Gelb for technical assistance. DNA clones for GABA receptor subunits were generous gifts from Dr. Paul Whiting, Merck Sharp, and Dohme Research Labs (Essex, UK). We also thank Profs. Keith Miller (Harvard Medical School, Boston, MA) and Joseph Henry Steinbach (Washington University, St. Louis, MO) for their comments on this manuscript.

Correspondence should be addressed to Dr. Stuart A. Forman, Department of Anesthesia and Critical Care, Massachusetts General Hospital, Harvard Medical School, Clinics 3, 55 Fruit Street, Boston, MA 02114. E-mail: saforman@partners.org. Copyright (C) 2002 Society for Neuroscience $0270-6474 / 02 / 228411-11 \$ 15.00 / 0$ and amplitudes, whereas $\alpha_{1}$ (L264T) $\beta_{2} \gamma_{2 L}$ currents desensitized extremely slowly. Deactivation of wild-type currents displayed two rates and slowed after partial desensitization, whereas currents from both mutants deactivated slowly with single rate constants that were unaffected by desensitization. These results indicate that both $\alpha_{1}(\mathrm{~L} 264 \mathrm{~T})$ and $\alpha_{1}(\mathrm{~S} 270 \mathrm{I})$ mutations increase the gating efficacy of receptors by slowing channel closing, which accounts for nearly all of the similar changes that they produce in macrocurrent dynamics. Because the $\alpha_{1}(\mathrm{~S} 270 \mathrm{I})$ mutation uncouples its gating effects from those on rapid desensitization, these two processes are necessarily associated with movements of distinct receptor structures (gates). The effects of the $\alpha_{1}(\mathrm{~L} 264 \mathrm{~T})$ mutation suggest that the conserved leucines may play a role in gating-desensitization coupling.

Key words: GABA receptor; acetylcholine receptor; ion channel; gating; desensitization; pore; electrophysiology

and with high probability after agonist binding, driven by increased affinity (Neubig et al., 1982; Jackson et al., 1990; Galzi and Changeux, 1994; Chang and Weiss, 1999). Fast receptor desensitization may help determine the magnitude and shape of GABAergic IPSCs, both by truncating activation and prolonging deactivation (Jones and Westbrook, 1995; Overstreet et al., 2000; Burkat et al., 2001).

Auerbach and Akk (1998) proposed that $\mathrm{nACh}$ receptor gating and desensitization are movements of independent gates that are energetically coupled. A number of studies has suggested that $\mathrm{GABA}_{\mathrm{A}}$ receptor desensitization is negatively coupled to gating, i.e., desensitization proceeds only from closed states (Jones and Westbrook, 1995; Haas and Macdonald, 1999; Li and Pearce, 2000). However, nonequilibrium single-channel studies indicate that $\mathrm{GABA}_{\mathrm{A}}$ receptors desensitize from both closed and open states with comparable rates (Burkat et al., 2001). Structural studies implicate TM2 domains in gating dynamics and suggest that they form gating structures in $\mathrm{nACh}$ and $\mathrm{GABA}_{\mathrm{A}}$ receptors (Xu and Akabas, 1996; Wilson and Karlin, 2001). Less is known about structures involved in fast desensitization. Bianchi et al. (2001) reported that desensitization of $\mathrm{GABA}_{\mathrm{A}}$ receptors containing $\gamma_{2}$ versus $\delta$ subunits was unaffected by swapping their highly homologous TM2 domains. Bianchi and Macdonald (2001) found that mutation of a conserved leucine in the $\mathrm{GABA}_{\mathrm{A}}$ receptor $\gamma$ subunit TM2 domain both enhanced gating and slowed the apparent rate of desensitization, attributing this to negative gating-desensitization coupling. It is unknown whether other mutations within TM2 domains that affect gating also alter desensitization, as implied by coupled mechanisms. 
We focused on two single amino acid mutations that are known to enhance GABA sensitivity in recombinant $\alpha_{1} \beta_{2} \gamma_{2 L} \mathrm{GABA}_{\mathrm{A}}$ receptors, $\alpha_{1}(\mathrm{~L} 264 \mathrm{~T})$ and $\alpha_{1}(\mathrm{~S} 270 \mathrm{I})$. L264 is one of the highly conserved TM2-9' leucines found in all superfamily subunits. Replacing these 9' leucines with serines or threonines in $\mathrm{GABA}_{\mathrm{A}}, \mathrm{nACh}$, or $5-\mathrm{HT}_{3}$ receptors apparently stabilizes open states whether agonists are bound or not, decreasing agonist $\mathrm{EC}_{50}$ values, prolonging channel openings, and increasing activation in the absence of agonist (Revah et al., 1991; Yakel et al., 1993; Filatov and White, 1995; Labarca et al., 1995; Tierney et al., 1996; Chang and Weiss, 1998, 1999; Dalziel et al., 2000). The $\alpha_{1}$ (S270I) mutation alters receptor modulation by alcohol and anesthetics (Mihic et al., 1997; Koltchine et al., 1999; Ueno et al., 1999). Like $\alpha_{1}(\mathrm{~L} 264 \mathrm{~T}), \alpha_{1}(\mathrm{~S} 270 \mathrm{I})$ reduces $\mathrm{GABA} \mathrm{EC}_{50}$, but whether it stabilizes open states is unknown. Activation, rapid desensitization, and deactivation kinetics of $\alpha_{1} \beta_{2} \gamma_{2 L}$ GABA $_{\mathrm{A}}$ receptors containing these mutations have not been reported previously. Given the proximity of these two TM2 residues and the similar impacts of the mutations on GABA EC $\mathrm{E}_{50}$, we hypothesized that both mutations would cause similar changes in molecular dynamic behavior.

We used submillisecond GABA concentration jumps to elicit macrocurrents from voltage-clamped patches and cells expressing $\mathrm{GABA}_{\mathrm{A}}$ receptors, deriving both equilibrium and kinetic activation, desensitization, resensitization, and deactivation data. Receptor activity in the absence of GABA was assessed electrophysiologically using high concentrations of picrotoxin. Our results indicate that both mutations enhance conduction gating. The $\alpha_{1}(\mathrm{~S} 270 \mathrm{I})$ mutation alters gating but not desensitization, indicating that the status of the $\mathrm{GABA}_{\mathrm{A}}$ receptor conduction gate can be uncoupled from desensitization. In contrast, the $\alpha_{1}(\mathrm{~L} 264 \mathrm{~T})$ mutation affects both conduction gating and desensitization. Thus, some, but not all, parts of the pore domain that affect the gating mechanism also couple to desensitization.

\section{MATERIALS AND METHODS}

Site-directed mutagenesis. cDNAs encoding $\alpha_{1}, \beta_{2}$, and $\gamma_{2 \mathrm{~L}}$ subunits of the human $\mathrm{GABA}_{\mathrm{A}}$ receptor in pCDM8 vectors (Invitrogen, Carlsbad, CA) were supplied by Dr. Paul J. Whiting (Merck Sharp and Dohme Research Labs, Essex, UK). cDNAs for $\alpha_{1}(\mathrm{~S} 270 \mathrm{I})$ and $\alpha_{1}(\mathrm{~L} 264 \mathrm{~T})$ were constructed using high-fidelity PCR oligonucleotide-directed mutagenesis. The presence of the mutations and absence of stray mutations in the cDNAs were confirmed by dideoxynucleotide sequencing.

Transient expression of recombinant $G A B A_{A}$ receptors. Human embryonic kidney cells (HEK293) [American Type Culture Collection (ATCC), Rockville, MD] were cultured in minimum essential Eagle medium (ATCC), supplemented with $10 \%$ horse serum and $1 \%$ penicillin-streptomycin (all from Life Technologies, Grand Island, NY), and maintained at $37^{\circ} \mathrm{C}$ in a $5 \% \quad \mathrm{CO}_{2}$ incubator. Cells were plated on protamine-coated glass coverslips. Transient expression of receptor channels was achieved by transfecting (Chen and Okayama, 1987) cells with cDNA mixtures for $\mathrm{GABA}_{\mathrm{A}}$ receptors encoding wild-type $\alpha_{1} \beta_{2} \gamma_{2 \mathrm{~L}}$, $\alpha_{1}(\mathrm{~S} 270 \mathrm{I}) \beta_{2} \gamma_{2 \mathrm{~L}}$, or $\alpha_{1}(\mathrm{~L} 264 \mathrm{~T}) \beta_{2} \gamma_{2 \mathrm{~L}}$ at a w/w ratio of $1 \alpha: 2 \beta: 5 \gamma($ or $1 \alpha: 2 \beta$ for $\gamma$-less controls). Cells were cotransfected with an expression plasmid $(\pi \mathrm{H} 3-\mathrm{CD} 8$; Jurman et al., 1994) for the lymphocyte surface antigen CD8- $\alpha$, which was a gift from Dr. Gary Yellen (Harvard Medical School, Boston, MA). Cells were cultured for $36-72 \mathrm{hr}$ after transfection and incubated briefly with polystyrene microspheres and precoated with anti-CD8 antibody (Dynabeads M-450 CD8; Dynal, Great Neck, NY). Transfected cells expressing CD8, which correlated with the presence of GABA-activated currents, were identified by adhering microspheres using phase-contrast microscopy.

$G A B A_{A}$ receptor electrophysiology. For electrophysiology, culture medium was replaced by an extracellular solution containing (in $\mathrm{mM}$ ): 162 $\mathrm{NaCl}, 5.3 \mathrm{KCl}, 0.67 \mathrm{Na}_{2} \mathrm{HPO}_{4}, 0.22 \mathrm{KH}_{2} \mathrm{PO}_{4}, 15 \mathrm{HEPES}, 5.6$ glucose, and $2 \mathrm{CaCl}_{2}$, adjusted to a $\mathrm{pH}$ of 7.30 with $\mathrm{NaOH}$. Patch pipettes were fabricated from borosilicate glass (Fisher Scientific, Pittsburgh, PA), fire polished to open tip resistances of 2-5 M $\Omega$, and filled with intracellular solution containing (in mM): $140 \mathrm{KCl}, 2 \mathrm{MgCl}_{2}, 11$ EGTA, $10 \mathrm{HEPES}$, and 10 glucose, adjusted to a $\mathrm{pH}$ of 7.30 with $\mathrm{KOH}$. Extracellular solutions containing GABA, diazepam, or picrotoxin (all from Sigma, St. Louis, MO) were prepared shortly before experiments. Experiments were performed at room temperature $\left(20-22^{\circ} \mathrm{C}\right)$ using standard outsideout or whole-cell patch-clamp techniques. For whole-cell recordings, the smallest cells (diameter of $\leq 6 \mu \mathrm{m}$; to increase mechanical stability and to decrease solution exchange time) were lifted from the coverslips. Patches or cells were voltage clamped at $-50 \mathrm{mV}$ during recordings. Pipette capacitance and series resistance were compensated in the whole-cell mode. Currents through the patch-clamp amplifier (Axopatch 200A; Axon Instruments, Foster City, CA) were filtered (eight-pole bessel, 2-5 $\mathrm{kHz}$ ) and digitized at $2-20 \mathrm{kHz}$ using commercial software (pClamp 8.0; Axon Instruments).

Rapid GABA application. Solutions were applied to patches or whole cells using a piezo-driven quad $(2 \times 2)$ capillary tube capable of switching between four flowing solutions (Forman, 1999). Solution exchange times for switching between adjacent solutions were $0.1-0.5 \mathrm{msec}$, measured as the $10-90 \%$ rise time for open pipette junction currents. This is also the effective time for solution changes for excised patches. Wholecell activation times at saturating GABA concentrations were measured to be $<1.5 \mathrm{msec}$ with cells $<6 \mu \mathrm{m}$ in diameter Larger cells slowed down solution exchange times and were not studied. Gravity-driven solutions in each of the four capillary lumens could be changed in $\sim 60 \mathrm{sec}$ using upstream selector valves coupled to reservoirs. A continuous flow of external solution through the recording chamber prevented accumulation of transmitter in the bath.

Standard protocols repetitively applied different concentrations of GABA (1 $\mathrm{nm}$ to $10 \mathrm{~mm}$ ) as pulses of variable duration, as appropriate for each experiment (for details, see Results). A 20-40 sec interval between agonist pulses was used for recovery of channel activity from desensitization. Ensemble averages of between 4 and 10 GABA-activated responses were stored for each experiment (e.g., different low GABA concentrations) in a single patch or cell. For each type of receptor, at least three different patches or cells from at least two different batches of transfected cells were studied in each experimental condition (GABA concentration response, activation, desensitization, or deactivation).

Data analysis. GABA-evoked ensemble average currents were baseline corrected by subtracting leak currents (and currents attributable to spontaneously active channels) recorded in each sweep before GABA application. For the two concentration internally controlled GABAresponse experiments, current amplitudes in low GABA ( $\left.I_{\text {Low }}\right)$ just preceding the switch to control saturating GABA (1-10 mM) were normalized to the peak current just after the solution switch $\left(I_{\text {Sat }}\right)$. Peak current data from single-concentration sweeps were similarly normalized to a paired control sweep. Normalized currents were fitted with logistic (Hill) equations of the following form:

$$
\frac{I_{\mathrm{Low}}}{I_{\mathrm{Sat}}}=\frac{I_{\mathrm{max}}}{I_{\mathrm{Sat}}} \times \frac{[\mathrm{GABA}]^{n H}}{[\mathrm{GABA}]^{n H}+\mathrm{EC}_{50}^{n H}},
$$

where $I_{\text {max }} / I_{\text {Sat }}$ is the maximum normalized current, $\mathrm{EC}_{50}$ is the concentration eliciting a half-maximal response, and $n H$ is the Hill coefficient of activation.

Activation rates were derived from multiexponential fits to the rising phase of currents (inverted) after jumping into GABA. Exponential fits for activation were improved by restricting the data set to points between $\sim 10 \%$ activation (beyond the "foot") and into the desensitization phase when it was present. The positive amplitude component of the fit was taken as the activation rate, as desensitization represented negative exponential components. For fast activation at GABA $\geq 10 \mu \mathrm{M}$, only patch currents were analyzed. For lower GABA concentrations, large currents were most readily recorded from whole cells. Although solution exchange was slower at cells than at patches, the apparent solution exchange rate was readily detected at high GABA (1-10 mM) in cells. Thus, by comparing activation rates at low and high GABA, we could discern when activation at low GABA was limited by GABA binding rather than by solution exchange.

Desensitization rates were derived from exponential fits to the decaying current phase between the peak of activation and the termination of GABA application. A constant term, representing steady-state desensitization, was unconstrained in the fits.

Deactivation rates were derived from exponential fits to the decaying current after removal of GABA. Depending on the number of exponential components, single, double, or triple exponential functions were fitted to these current decay phases using a Levenberg-Marquardt search 

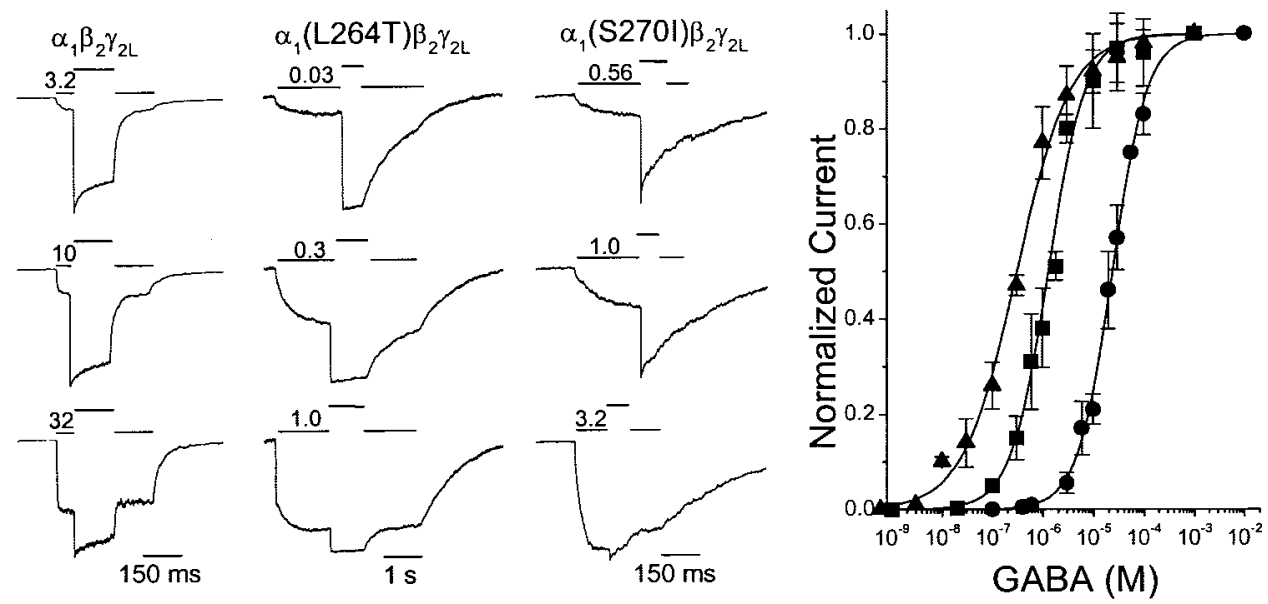

Figure 1. GABA-dependent peak currents of wild-type $\alpha_{1} \beta_{2} \gamma_{2 \mathrm{~L}}, \alpha_{1}(\mathrm{~L} 264 \mathrm{~T}) \beta_{2} \gamma_{2 \mathrm{~L}}$, and $\alpha_{1}(\mathrm{~S} 270 \mathrm{I}) \beta_{2} \gamma_{2 \mathrm{~L}} \mathrm{GABA}_{\mathrm{A}}$ receptors. Left panels, Traces are examples of currents recorded from voltage-clamped membrane patches expressing wild-type or mutant $\mathrm{GABA}_{\mathrm{A}}$ receptors, elicited with a two-concentration GABA activation protocol. Initial activation at a low GABA concentration was followed by a rapid jump to $1 \mathrm{~mm}$ GABA in the same sweep and then reversal of these steps. Solid lines above traces indicate timing of the different GABA applications and the low GABA concentration used (micromolar). Longer exposures to low GABA were used with $\alpha_{1}(\mathrm{~L} 264 \mathrm{~T}) \beta_{2} \gamma_{21}$ receptors because of their very high sensitivity to GABA and slow desensitization. Right, Relative peak currents at low versus saturating $(1-10 \mathrm{~mm})$ GABA were derived from traces, by calculating the ratio of currents immediately before $\left(I_{\text {Low }}\right)$ and after $\left(I_{\text {Sat }}\right)$ the jump from low to high GABA. Combined normalized data (average \pm SD) from patches and cells are plotted. The lines through data points represent Equation 1 (see Materials and Methods) fitted to data. Wild type (circles), $\mathrm{EC}_{50}$ of 25 $\mu \mathrm{M} ; n H=1.3 . \alpha_{1}(\mathrm{~L} 264 \mathrm{~T}) \beta_{2} \gamma_{2 \mathrm{~L}}$ (triangles), $\mathrm{EC}_{50}$ of $0.30 \mu \mathrm{M} ; n H=0.83 . \alpha_{1}(\mathrm{~S} 270 \mathrm{I}) \beta_{2} \gamma_{2 \mathrm{~L}}$ (squares), $\mathrm{EC}_{50}$ of $1.3 \mu \mathrm{M} ; n H=1.3$. protocol and least-squares minimization. The number of exponential components was increased until the addition of another component did not significantly improve the fit using an $F$ test $(p<0.01)$. Two-tailed Student's $t$ tests were used for statistical comparisons of the various properties of mutant and wild-type receptors. Nonlinear and linear least-squares fits and statistical analyses were performed using commercial software [Origin v5.0 (Microcal, Northampton, MA) or Clampfit v8.0 (Axon Instruments)]. All results are reported as means \pm SD.

Kinetic modeling. Model-generated current data were calculated using MATLAB software (The Mathworks, Natick, MA) based on state matrix ( $Q$ matrix) differential equations and methods that have been described by Colquhoun and Hawkes (1995). Iteration time intervals for the calculations were 0.1-1 msec. Model-generated current data were imported into Origin worksheets and analyzed by the same methods used for electrophysiologic recordings.

Evaluation of $G A B A_{A}$ receptor subunit expression. $\mathrm{GABA}_{\mathrm{A}} \mathrm{R}$ expression studies in HEK293 cells may be subject to artifacts attributable to endogenous expression of subunits (Ueno et al., 1996). We found that untransfected HEK293 cells had no endogenous GABA-activatable currents. Whole-cell currents recorded from cells transfected with wild-type and mutant cDNAs were generally above $500 \mathrm{pA}$, suggesting that combinations with endogenous subunits do not contribute significantly to our results. In addition, some investigators (Boileau and Czajkowski, 1999) have suggested that the $\gamma$ subunit may not be efficiently incorporated into $\mathrm{GABA}_{\mathrm{A}}$ Rs under some conditions, whereas others have reported that $\gamma$ is efficiently incorporated into $\mathrm{GABA}_{\mathrm{A}}$ Rs when it is cotransfected with $\alpha$ and $\beta$ subunits (Verdoorn et al., 1990; Hadingham et al., 1992; Krampfl et al., 1998). Several results lead us to conclude that $\gamma_{2 L}$ was efficiently incorporated into the $\mathrm{GABA}_{\mathrm{A}} \mathrm{Rs}$ we studied. First, the $\mathrm{GABA} \mathrm{EC}_{50}$ of $\mathrm{GABA}_{\mathrm{A}}$ Rs from cells transfected with only $\alpha_{1}$ and $\beta_{2}$ cDNAs ( $\gamma$-less) was consistently and significantly lower than the $\mathrm{EC}_{50}$ determined from cells transfected with all three subunits [3.9 $\pm 0.23 \mu \mathrm{M}$ for $\alpha_{1} \beta_{2}(n=5)$ vs $25 \pm$ $0.7 \mu \mathrm{M}$ for $\alpha_{1} \beta_{2} \gamma_{2 \mathrm{~L}}$ ]. We did not detect any evidence for a mixture of two populations of receptors in GABA concentration responses. Second, we found no difference in the GABA sensitivity and kinetic behavior of $\mathrm{GABA}_{\mathrm{A}} \mathrm{R}$ currents from cells that were transfected with our usual cDNA mix versus those from cells in which the relative stoichiometry of $\gamma_{2 L}$ cDNA was increased fourfold. Finally, we found that submaximal GABA-activated currents $\left(\mathrm{EC}_{5-10}\right)$ from cells expressing $\alpha_{1} \beta_{2} \gamma_{2 \mathrm{~L}}$ receptors were enhanced threefold $(n=4)$ by $3 \mu \mathrm{M}$ diazepam, which is known to require a $\gamma$ subunit (Pritchett et al., 1989), whereas similar experiments in $\alpha_{1} \beta_{2}$ receptors showed no enhancement by $3 \mu \mathrm{M}$ diazepam $(n=3)$.

\section{RESULTS}

\section{Both $\alpha_{1}$ (L264T) and $\alpha_{1}$ (S270I) mutations enhance receptor gating}

\section{$G A B A$-dependent peak currents}

The equilibrium between resting receptors and GABA-activated open receptors depends on both GABA binding-unbinding and gating efficacy and is reflected in the GABA-dependent peak currents elicited by rapid GABA concentration jumps. Previous studies in oocytes and HEK293 cells have reported enhanced GABA sensitivity for receptors containing $\alpha_{1}(\mathrm{~L} 264 \mathrm{~T})$ or $\alpha_{1}(\mathrm{~S} 270 \mathrm{I})$ mutations (Chang et al., 1996; Koltchine et al., 1999; Scheller and Forman, 2001), but none have studied both mutants in the $\alpha_{1} \beta_{2} \gamma_{2 \mathrm{~L}}$ subunit background or used submillisecond GABA concentration jumps. For each type of $\mathrm{GABA}_{\mathrm{A}}$ receptor, we assessed relative peak-activated currents over a range of GABA concentrations using a two-concentration protocol, in which currents were initially activated with a low concentration of agonist until the peak current amplitude was reached, followed by a rapid jump to saturating GABA (1-10 mM). The peak current ratio for low versus saturating GABA $\left(I_{\text {Low }} / I_{\text {Sat }}\right)$ was thereby assessed within a few milliseconds in a single internally controlled sweep, minimizing the effects of both current rundown and desensitization on this measurement. Initial GABA pulse durations of $10 \mathrm{msec}$ up to $1.5 \mathrm{sec}$ were used to reach peak currents, because of the large variability in activation rates over the GABA concentration range tested ( $1 \mathrm{~nm}$ to $10 \mathrm{~mm})$.

Representative current traces for the wild-type and mutant $\mathrm{GABA}_{\mathrm{A}}$ receptor are shown in Figure 1. Peak control currents varied between patches or cells because of varying numbers of active receptors. Some variability in the $\mathrm{I}_{\mathrm{Low}} / \mathrm{I}_{\mathrm{Sat}}$ ratios was attributable to the use of slightly different initial pulse lengths (resulting in variable desensitization), as well as differences in currents from patches and small cells, which displayed different apparent activation and desensitization rates. However, these variations were not large, because $\mathrm{EC}_{50}$ values derived from independent experiments in patches and cells differed by $<30 \%$. Combined data from all wild-type patches and cells studied (Fig. 1, circles) were fit using Equation 1 (Materials and Methods) with an $\mathrm{EC}_{50}$ of $25 \mu \mathrm{M}$.

Incorporation of the $\alpha_{1}(\mathrm{~L} 264 \mathrm{~T})$ mutation in $\alpha_{1} \beta_{2} \gamma_{2 \mathrm{~L}} \mathrm{GABA}_{\mathrm{A}}$ receptors resulted in a large increase in sensitivity to GABA, with concentrations in the low micromolar range eliciting peak currents that were near maximal (Fig. 1). Activation of $\alpha_{1}(\mathrm{~L} 264 \mathrm{~T}) \beta_{2} \gamma_{2 \mathrm{~L}}$ $\mathrm{GABA}_{\mathrm{A}}$ receptors was very slow at the lowest range of GABA tested, requiring GABA applications of up to $1.5 \mathrm{sec}$ to reach steady-state current. However, desensitization of these receptors was also very slow, so relative peak currents were very consistent 


\begin{tabular}{|c|c|c|c|}
\hline & $\alpha_{1} \beta_{2} \gamma_{2 \mathrm{~L}}$ & $\alpha_{1}(\mathrm{~L} 264 \mathrm{~T}) \beta_{2} \gamma_{2 \mathrm{~L}}$ & $\alpha_{1}(\mathrm{~S} 270 \mathrm{I}) \beta_{2} \gamma_{2 \mathrm{~L}}$ \\
\hline Fraction spontaneously active receptors ${ }^{a}$ & $<0.0001$ & $0.36 \pm 0.15^{b}(6)$ & $0.005 \pm 0.0013^{b}(6)$ \\
\hline \multicolumn{4}{|l|}{$\mathrm{EC}_{50}(\mu \mathrm{M})$} \\
\hline Internal control & $25 \pm 0.7(30)$ & $0.30 \pm 0.023^{c}(8)$ & $1.3 \pm 0.10^{c}(15)$ \\
\hline Paired controls & $27 \pm 2.9(4)$ & $0.35 \pm 0.073^{c}(3)$ & $2.1 \pm 0.33^{c}(4)$ \\
\hline \multicolumn{4}{|l|}{ Hill coefficient } \\
\hline Internal control & $1.3 \pm 0.05$ & $0.83 \pm 0.047^{c}$ & $1.3 \pm 0.13$ \\
\hline Paired controls & $1.1 \pm 0.11$ & $0.8 \pm 0.12^{c}$ & $1.0 \pm 0.15$ \\
\hline \multicolumn{4}{|l|}{ Activation rates } \\
\hline Low GABA $\left(\mathrm{sec}^{-1}\right)$ & $8 \pm 1.0(8)$ & $4 \pm 1.8^{c}(12)$ & $5 \pm 1.4^{c}(7)$ \\
\hline High GABA $\left(\sec ^{-1}\right)$ & $3400 \pm 1500(30)$ & $3900 \pm 1500(8)$ & $3800 \pm 2500(21)$ \\
\hline Fast desensitization $\left(\mathrm{sec}^{-1}\right)$ & $20 \pm 10.8(12)$ & & $20 \pm 10.4(7)$ \\
\hline Slow desensitization $\left(\mathrm{sec}^{-1}\right)$ & $1.0 \pm 0.35$ & $<0.1^{c}(8)$ & $0.9 \pm 0.25$ \\
\hline Percentage fast & $30 \pm 9.0$ & & $35 \pm 10$ \\
\hline Percentage slow & $70 \pm 8.9$ & $100^{c}$ & $65 \pm 10$ \\
\hline Fast resensitization $\left(\mathrm{sec}^{-1}\right)$ & $10 \pm 5.0(3)$ & & \\
\hline Slow resensitization $\left(\mathrm{sec}^{-1}\right)$ & $0.076 \pm 0.0077$ & & $0.05 \pm 0.0025^{c}(3)$ \\
\hline Percentage fast & $30 \pm 10$ & & \\
\hline Percentage slow & $70 \pm 10$ & & $100^{c}$ \\
\hline Fast deactivation $\left(\mathrm{sec}^{-1}\right)$ & $50 \pm 13(7)$ & & \\
\hline Slow deactivation $\left(\mathrm{sec}^{-1}\right)$ & $7 \pm 2.1$ & $1.1 \pm 0.40^{c}(7)$ & $2.9 \pm 0.63^{c}(6)$ \\
\hline Percentage fast & $60 \pm 17$ & & \\
\hline Percentage slow & $40 \pm 17$ & $100^{c}$ & $100^{c}$ \\
\hline
\end{tabular}

Values are reported as mean $\pm \mathrm{SD}$. The number of experiments is reported in parentheses.

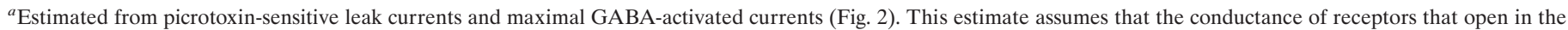
absence of GABA is identical to that when GABA is bound.

${ }^{b}$ Value differs from zero at $p \leq 0.05$.

${ }^{c}$ Value differs from wild-type $\mathrm{GABA}_{\mathrm{A}}$ receptors at $p \leq 0.01$.

between patches and cells. The combined data (Fig. 1, triangles) were fitted with an $\mathrm{EC}_{50}$ of $0.30 \mu \mathrm{M}, \sim 80$-fold lower than the wild-type value.

$\mathrm{GABA}_{\mathrm{A}}$ receptors containing the $\alpha_{1}(\mathrm{~S} 270 \mathrm{I})$ mutation also showed increased sensitivity to GABA activation (Fig. 1). GABA concentrations near $1 \mu \mathrm{M}$ elicited approximately half the current seen with $1 \mathrm{~mm}$ GABA. Combined patch and cell data for $\alpha_{1}(\mathrm{~S} 270 \mathrm{I}) \beta_{2} \gamma_{2 \mathrm{~L}} \mathrm{GABA}_{\mathrm{A}}$ receptors (Fig. 1, squares) were fitted with an $\mathrm{EC}_{50}$ of $1.3 \mu \mathrm{M}, \sim 20$-fold lower than the wild-type value.

Although the single-sweep internally controlled concentration-response method is convenient and minimizes uncertainty caused by rundown, it may result in $\mathrm{EC}_{50}$ values and Hill coefficients that differ from those derived from traditional concentration-response measurements, in which peak currents at low and saturating agonist concentrations are measured in separate sweeps. For comparison with the two-concentration method, normalized peak GABA-elicited responses were recorded from patches expressing wild-type or mutant $\mathrm{GABA}_{\mathrm{A}}$ receptors using singleconcentration pulses. In patches expressing both wild-type and $\alpha_{1}(\mathrm{~L} 264 \mathrm{~T}) \beta_{2} \gamma_{2 \mathrm{~L}}$ GABA $\mathrm{A}$ receptors, $\mathrm{EC}_{50}$ values derived using the single-concentration method (Table 1) were very similar to those derived from internally controlled sweeps. For $\alpha_{1}(\mathrm{~S} 270 \mathrm{I}) \beta_{2} \gamma_{2 \mathrm{~L}}$ $\mathrm{GABA}_{\mathrm{A}}$ receptors, the $\mathrm{EC}_{50}$ derived using single-concentration sweeps was $2.1 \mu \mathrm{M}, 1.6$ times the $\mathrm{EC}_{50}$ derived from internally controlled sweeps. These significantly different results from the two normalization methods are expected when current activation with agonist concentrations near $\mathrm{EC}_{50}$ is slow compared with desensi- tization, which is the case for the $\alpha_{1}(\mathrm{~S} 270 \mathrm{I})$ mutant but not for wild-type or the $\alpha_{1}(\mathrm{~L} 264 \mathrm{~T})$ mutant (see below).

\section{Spontaneous activation}

Spontaneous receptor activation represents a measure of the equilibrium between resting and open channels that is independent of GABA binding. TM2 domain mutations that affect the open-closed gating equilibrium appear to affect gating equally whether or not GABA is bound (Chang and Weiss, 1999). We estimated spontaneous receptor activation electrophysiologically by measuring the portion of the holding current at zero GABA that could be inhibited by high concentrations of the channel blocker picrotoxin (1 mM). To estimate spontaneous current as a fraction of total receptor activity, the picrotoxin-sensitive current, $I_{\mathrm{PTX}}-I_{\text {hold }}$, was normalized to the difference between $I_{\mathrm{PTX}}$ and the maximal GABA-activated current (1-10 mM GABA) in the same patch: $\left(I_{\mathrm{PTX}}-I_{\text {hold }}\right) /\left(I_{\mathrm{PTX}}-I_{\mathrm{GABA}}\right)$.

Holding currents for voltage-clamped $(-50 \mathrm{mV})$ cells and patches expressing wild-type $\alpha_{1} \beta_{2} \gamma_{2 \mathrm{~L}}$ or $\alpha_{1}(\mathrm{~S} 270 \mathrm{I}) \beta_{2} \gamma_{2 \mathrm{~L}}$ channels were generally very small compared with peak GABA-activated currents. In comparison, cells and patches expressing $\alpha_{1}(\mathrm{~L} 264 \mathrm{~T}) \beta_{2} \gamma_{2 \mathrm{~L}}$ channels consistently displayed large holding currents. The application of picrotoxin did not perceptibly affect wild-type holding currents (Fig. 2, left). Because the baseline noise level in our whole-cell recordings was 1-2 pA, we were able to detect a change of $\sim 1 \mathrm{pA}$ in holding currents. The absence of any picrotoxin-induced change in wild-type holding current, 


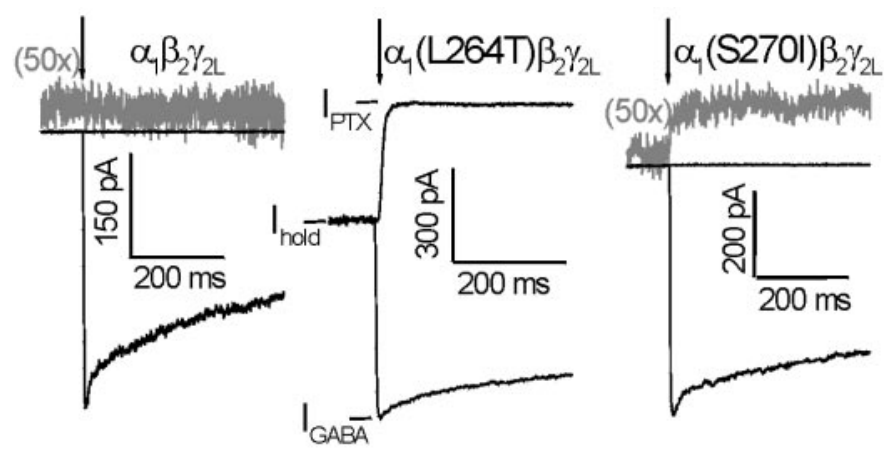

Figure 2. GABA-independent activation estimated from picrotoxinsensitive "leak" currents. Membrane patches expressing wild-type or mutant $\mathrm{GABA}_{\mathrm{A}}$ receptors were voltage clamped at $-50 \mathrm{mV}$ and exposed to rapidly applied pulses of $1 \mathrm{~mm}$ picrotoxin (upward traces) or $1 \mathrm{~mm}$ GABA (downward traces). Both mutant receptors exhibited picrotoxinsensitive holding currents, whereas wild type did not. The fraction of receptors active in the absence of GABA was estimated from the ratio $\left(I_{\mathrm{PTX}}-I_{\text {hold }}\right) /\left(I_{\mathrm{PTX}}-I_{\mathrm{GABA}}\right)$. Results are summarized in Table 1.

associated with maximal GABA-activated currents up to $5 \mathrm{nA}$, indicates that wild-type channels open spontaneously $<0.01 \%$ of the time. In contrast, picrotoxin dramatically reduced $\alpha_{1}$ (L264T) $\beta_{2} \gamma_{2 \mathrm{~L}}$ holding currents (Fig. 2, middle), indicating that $36 \%$ of $\alpha_{1}$ (L264T) $\beta_{2} \gamma_{2 L}$ receptors were conducting in the absence of GABA (Table 1). In addition, picrotoxin significantly decreased the holding current in patches and cells expressing $\alpha_{1}(\mathrm{~S} 270 \mathrm{I}) \beta_{2} \gamma_{2 \mathrm{~L}}$ receptors (Fig. 2, right; Table 1), indicating that $0.5 \%$ of these receptors were conducting in the absence of GABA.

\section{Gating enhancement by mutations is attributable to slow channel closure}

The rate of current onset recorded during initial GABA application (activation) is a function of GABA binding rates and channel opening rates for ligand-bound receptors. At very high GABA, the activation rate approximates the channel opening rate. At lower GABA, activation is limited by concentration-dependent binding and, at very low concentrations, may reflect channel closing or unbinding steps (Celentano and Wong, 1994; Maconochie et al., 1994). To discern whether mutant effects on gating were associated with changes in GABA association or channel opening rates, we studied current activation over a wide range of GABA concentrations.

For wild-type and mutant channel currents, activation rates increased with increasing concentrations of GABA (Fig. 3). At 1 $\mu \mathrm{M} \leq[\mathrm{GABA}] \leq 1 \mathrm{~mm}$, wild-type current activation rates increased in direct proportion to GABA. The slope of an errorweighted fitted line through these data are $0.95 \pm 0.065 \times 10^{7}$ $\mathrm{M}^{-1} \mathrm{sec}^{-1}$, the apparent rate of GABA binding. Above $1 \mathrm{~mm}$ GABA, activation rates show asymptotic behavior, with peak rates in patches ranging from 2000 to $5000 \mathrm{sec}^{-1}$ at $1-10 \mathrm{mM}$ GABA. At the lowest GABA concentrations that elicited currents suitable for analysis $(0.2-0.5 \mu \mathrm{M})$, we observed an asymptotic low rate for wild-type current activation (Fig. 3, left inset). The average low GABA activation rate for wild-type currents was $8 \mathrm{sec}^{-1}$, similar to that reported for granule cell $\mathrm{GABA}_{\mathrm{A}}$ currents (Maconochie et al., 1994).

Activation rates for $\alpha_{1}(\mathrm{~L} 264 \mathrm{~T}) \beta_{2} \gamma_{2 \mathrm{~L}}$ and $\alpha_{1}(\mathrm{~S} 270 \mathrm{I}) \beta_{2} \gamma_{2 \mathrm{~L}}$ $\mathrm{GABA}_{\mathrm{A}}$ receptor currents were nearly identical to those from wild type at equal GABA concentrations $>0.5 \mu \mathrm{M}$ (Fig. 3, middle and right), despite eliciting larger proportions of maximal peak currents. In the $1 \mu \mathrm{M}$ to $1 \mathrm{mM}$ range, the apparent GABA binding rates for $\alpha_{1}(\mathrm{~L} 264 \mathrm{~T}) \beta_{2} \gamma_{2 \mathrm{~L}}$ and $\alpha_{1}(\mathrm{~S} 270 \mathrm{I}) \beta_{2} \gamma_{2 \mathrm{~L}} \mathrm{GABA}_{\mathrm{A}}$ receptors are $0.8 \pm 0.15 \times 10^{7} \mathrm{M}^{-1} \mathrm{sec}^{-1}$ and $0.9 \pm 0.11 \times 10^{7} \mathrm{M}^{-1} \mathrm{sec}^{-1}$, respectively. In addition, maximal activation rates for both mutant receptors, measured at 1-10 mM GABA in patches, closely match those of wild-type receptors (Table 1). The low GABA current activation rate asymptotes for $\alpha_{1}(\mathrm{~L} 264 \mathrm{~T}) \beta_{2} \gamma_{2 \mathrm{~L}}$ and $\alpha_{1}(\mathrm{~S} 270 \mathrm{I}) \beta_{2} \gamma_{2 \mathrm{~L}} \mathrm{GABA}_{\mathrm{A}}$ receptor currents were significantly lower than that for wild type ( $\sim 4$ and $5 \sec ^{-1}$, respectively; $\left.p \leq 0.01\right)$.

\section{The $\alpha_{1}(\mathrm{~L} 264 \mathrm{~T})$ mutation slows desensitization, whereas the $\alpha_{1}$ (S270l) mutation does not}

GABA receptor current decay in the continuous presence of saturating GABA (1-10 mm) was studied using long GABA pulses $(\geq 1.5 \mathrm{sec})$. Fast desensitization rates in both wild-type and $\alpha_{1}(\mathrm{~S} 270 \mathrm{I}) \beta_{2} \gamma_{2 \mathrm{~L}}$ receptors were assessed in excised outside-out patches. Desensitization of $\alpha_{1}(\mathrm{~L} 264 \mathrm{~T}) \beta_{2} \gamma_{2 \mathrm{~L}}$ receptors was also studied in whole cells using GABA pulses of $\leq 20 \mathrm{sec}$ in length.

Desensitization of GABA currents elicited from wild-type $\alpha_{1} \beta_{2} \gamma_{2 \mathrm{~L}} \mathrm{GABA}_{\mathrm{A}}$ receptors was variable, displaying two to three exponential components (Fig. 4, left) and a nonzero constant term, representing the steady-state current after prolonged desensitization. After GABA pulses of $5 \mathrm{sec}$, wild-type currents desensitized to a steady-state value averaging $8 \pm 5.3 \%$ of peak $(n=12)$. Three exponential components significantly improved nonlinear least-squares fits over two components in 5 of 12 patches $(F$ test at $p \leq 0.01)$. The rates and fractional amplitudes for the three resolved components were as follows: $\tau_{\text {fast }}^{-1}=70 \pm 29$ $\mathrm{sec}^{-1}, A_{\text {fast }}=0.2 \pm 0.16 ; \tau_{\text {int }}^{-1}=6 \pm 5.1 \mathrm{sec}^{-1}, A_{\text {int }}=0.2 \pm 0.11$; $\tau_{\text {slow }}^{-1}=0.7 \pm 0.35 \mathrm{sec}^{-1}, A_{\text {slow }}=0.5 \pm 0.16$. When these five traces were fitted with only two exponential components, the results were similar to those for the remaining seven traces, averaging $\sim 20$ and $1 \mathrm{sec}^{-1}$, respectively, for fast and slow decays (Table 1). Relative amounts of fast and slow desensitization varied from patch to patch, but on average, fast desensitization accounted for less than half of the current decay.

The $\alpha_{1}(\mathrm{~L} 264 \mathrm{~T})$ mutation dramatically reduced and slowed desensitization (Fig. 4, middle). After GABA (1 mM) pulses of $5 \mathrm{sec}$, desensitization reduced current from peak values by only $19 \pm$ $8.3 \%(n=8)$, and GABA pulses of $\leq 20 \mathrm{sec}$ produced $<40 \%$ desensitization. Desensitization in $\alpha_{1}(\mathrm{~L} 264 \mathrm{~T}) \beta_{2} \gamma_{2 \mathrm{~L}}$ currents was consistently slow in both patches and whole cells, although some currents showed several apparent phases of desensitization. Based on these results, $\alpha_{1}(\mathrm{~L} 264 \mathrm{~T}) \beta_{2} \gamma_{2 \mathrm{~L}} \mathrm{GABA}_{\mathrm{A}}$ receptors desensitize with a time constant of $>10 \mathrm{sec}$ and to a much lower degree than wild type (Table 1 ).

Desensitization of GABA currents elicited from $\alpha_{1}(\mathrm{~S} 270 \mathrm{I}) \beta_{2} \gamma_{2 \mathrm{~L}} \mathrm{GABA}_{\mathrm{A}}$ receptors was very similar to that observed in wild-type currents, displaying two to three exponential components (Fig. 4, right). After $5 \mathrm{sec}$ in $1 \mathrm{~mm}$ GABA, $\alpha_{1}(\mathrm{~S} 270 \mathrm{I}) \beta_{2} \gamma_{2 \mathrm{~L}}$ currents decayed to $11 \pm 7.7 \%$ of peak $(n=7)$. In four of seven patches, $F$ test analysis indicated significantly ( $p \leq$ 0.01 ) improved fits with three exponentials versus two. The average rates and fractional amplitudes for the three resolved components were as follows: $\tau_{\text {fast }}^{-1}=80 \pm 43 \mathrm{sec}^{-1}, A_{\text {fast }}=0.2 \pm 0.08$; $\tau_{\text {int }}^{-1}=9 \pm 5 \mathrm{sec}^{-1}, A_{\text {int }}=0.2 \pm 0.12 ; \tau_{\text {slow }}^{-1}=0.7 \pm 0.24 \mathrm{sec}^{-1}$, $A_{\text {slow }}=0.5 \pm 0.14$. Two component fits for these four patches were similar to the remaining three patches (Table 1). Neither the fitted rates of current decay nor the relative amount of fast and 

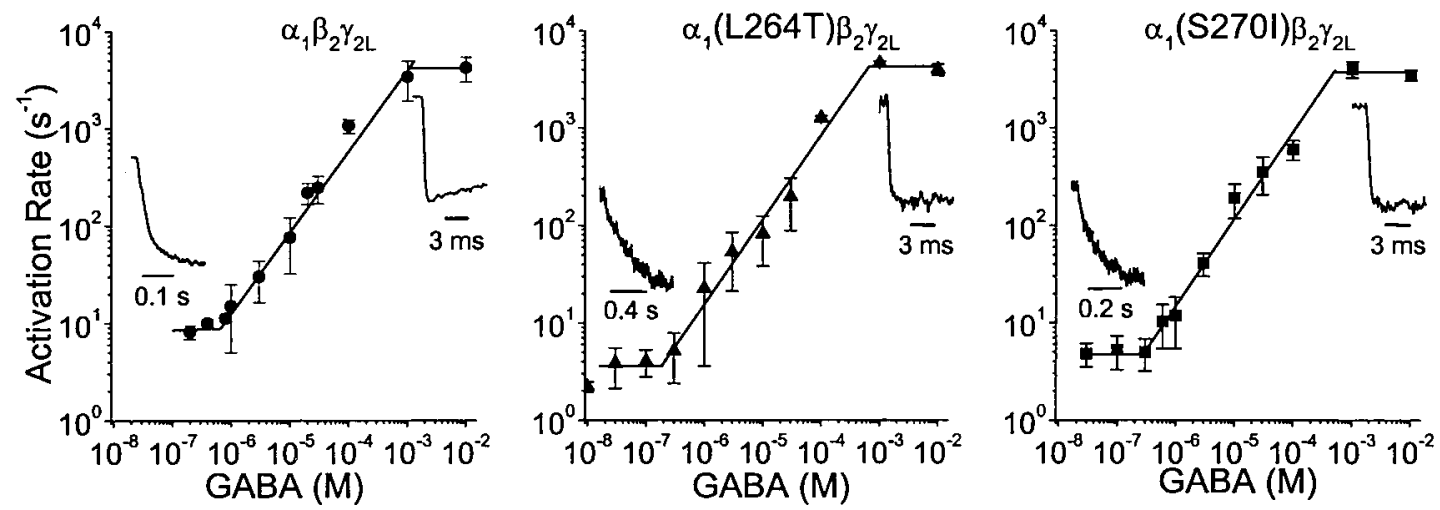

Figure 3. GABA-dependent activation rates for wild-type and mutant $\mathrm{GABA}_{\mathrm{A}}$ receptors. Panels are $\log -\log$ plots of average activation rates versus GABA concentration. Each point represents at least three experiments. The lines connecting data points between $0.5 \mu \mathrm{M}$ and $1 \mathrm{mM}$ GABA represent linear least-squares fits. Horizontal lines represent average rates at low and high GABA within the depicted ranges. Examples of current activation traces at both very low GABA and high GABA are shown as insets to each panel. Left, Wild type $\left.\left(\alpha_{1} \beta_{2} \gamma_{2 \mathrm{~L}}\right) ; 10^{-6} \mathrm{M} \mathrm{GABA}^{-1} \tau^{-1}=28.6 \mathrm{sec}{ }^{-1}\right) ; 10^{-2} \mathrm{M}$ GABA $\left(\tau^{-1}=4600 \mathrm{sec}^{-1}\right)$. Middle, $\alpha_{1}(\mathrm{~L} 264 \mathrm{~T}) \beta_{2} \gamma_{2 \mathrm{~L}} ; 10^{-7} \mathrm{M}$ GABA $\left(\tau^{-1}=3.4 \mathrm{sec}^{-1}\right) ; 10^{-2} \mathrm{M} \mathrm{GABA}\left(\tau^{-1}=3700 \mathrm{sec}^{-1}\right)$. Right,$\alpha_{1}(\mathrm{~S} 270 \mathrm{I}) \beta_{2} \gamma_{2 \mathrm{~L}} ; 10^{-7} \mathrm{M}$ GABA $\left(\tau^{-1}=7.3 \mathrm{sec}^{-1}\right) ; 10^{-2} \mathrm{M} \operatorname{GABA}\left(\tau^{-1}=3000 \mathrm{sec}^{-1}\right)$. Average activation parameters for all experiments are reported in Table 1 .
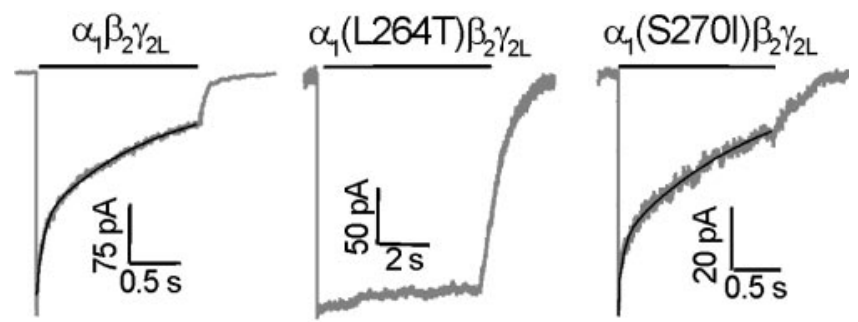

Figure 4. Desensitization kinetics of wild-type and mutant $\mathrm{GABA}_{\mathrm{A}}$ receptors. Examples of currents recorded from voltage-clamped membrane patches during long desensitizing pulses of 1-10 mM GABA. Lines above traces indicate the application of GABA. Exponential fits to the desensitizing current phases are shown overlaid on the currents. Left, Wild type $\left(\alpha_{1} \beta_{2} \gamma_{2 L}\right)$. Current decay during desensitization was best fitted with two exponentials $\left[\tau_{\text {fast }}^{-1}=18 \mathrm{sec}^{-1}(36 \%) ; \tau_{\text {slow }}^{-1}=0.97 \mathrm{sec}^{-1}(64 \%)\right]$. Middle, $\alpha_{1}(\mathrm{~L} 264 \mathrm{~T}) \beta_{2} \gamma_{2}$. Because of the small degree of desensitization during the $6 \mathrm{sec}$ GABA pulse, we were unable to fit an exponential function to these data. Right, $\alpha_{1}(\mathrm{~S} 270 \mathrm{I}) \beta_{2} \gamma_{2 \mathrm{~L}}$. Desensitization was best fit by two exponentials $\left[\tau_{\text {fast }}^{-1}=18 \mathrm{sec}^{-1}(25 \%) ; \tau_{\text {slow }}^{-1}=0.67 \mathrm{sec}^{-1}(75 \%)\right]$. Average desensitization parameters for all experiments are reported in Table 1 .

slow components for $\alpha_{1}(\mathrm{~S} 270 \mathrm{I}) \beta_{2} \gamma_{2 \mathrm{~L}}$ currents significantly differ from wild-type values (Table 1).

\section{Recovery from desensitization is slowed by the $\alpha_{1}$ (S270l) mutation}

Recovery of $\mathrm{GABA}_{\mathrm{A}}$ receptor response after desensitization was studied in patches expressing wild-type and $\alpha_{1}(\mathrm{~S} 270 \mathrm{I}) \beta_{2} \gamma_{2 \mathrm{~L}}$ $\mathrm{GABA}_{\mathrm{A}}$ receptors using a double-pulse protocol (data not shown). An initial $2 \mathrm{sec}$ pulse at $1 \mathrm{~mm}$ GABA was applied, resulting in $\sim 70 \%$ desensitization, followed by a variable period of recovery ( $20 \mathrm{msec}$ to $40 \mathrm{sec})$ and a second pulse of $1 \mathrm{~mm}$ GABA to elicit a maximal response from nondesensitized receptors. To correct for possible rundown or slow recovery, the second peak was normalized to the first peak for each sweep. Because desensitization of $\alpha_{1}(\mathrm{~L} 264 \mathrm{~T}) \beta_{2} \gamma_{2 \mathrm{~L}} \mathrm{GABA}_{\mathrm{A}}$ receptors was minimal, their recovery from desensitization was not studied.

Two phases of resensitization were seen with wild-type recep- tors. Fast resensitization accounted for $25-35 \%$ of recovery, with time constants ranging from 60 to $150 \mathrm{msec}$ (Table 1). Slow resensitization of wild-type receptors was characterized by a time constant of $13 \mathrm{sec}$. $\mathrm{GABA}_{\mathrm{A}}$ receptors containing the $\alpha_{1}(\mathrm{~S} 270 \mathrm{I})$ mutation displayed only a single slow resensitization phase with a time constant of $20 \mathrm{sec}$ (Table 1). Thus, the resensitization of $\alpha_{1}(\mathrm{~S} 270 \mathrm{I}) \beta_{2} \gamma_{2 \mathrm{~L}}$ was significantly slower than that of wild type.

\section{Both $\alpha_{1}(\mathrm{~L} 264 \mathrm{~T})$ and $\alpha_{1}(\mathrm{~S} 270 \mathrm{l})$ mutations slow deactivation and remove desensitization-deactivation coupling}

The current decay after removal of GABA represents transitions from active ligand-bound receptor states to inactive unbound states, including channel closure and GABA dissociation. In addition, desensitized $\mathrm{GABA}_{\mathrm{A}}$ receptors may reopen before GABA dissociation, prolonging deactivation (Jones and Westbrook, 1995). We assessed deactivation rates for wild-type and $\alpha_{1}(\mathrm{~S} 270 \mathrm{I}) \beta_{2} \gamma_{2 \mathrm{~L}} \mathrm{GABA}_{\mathrm{A}}$ receptor currents in excised patches after maximal GABA pulses of 10-3000 msec. Because of its slow desensitization, longer GABA pulses were sometimes used to study $\alpha_{1}(\mathrm{~L} 264 \mathrm{~T}) \beta_{2} \gamma_{2 \mathrm{~L}}$ deactivation.

Representative traces displaying deactivation of maximally activated wild-type and mutant $\mathrm{GABA}_{\mathrm{A}}$ receptor currents are shown in Figure 5. For $\alpha_{1} \beta_{2} \gamma_{2 \mathrm{~L}}$ currents, deactivation was best fitted with two exponentials (Fig. 5, left; Table 1), in agreement with previous studies on $\alpha_{1} \beta_{2} \gamma_{2 L}$ receptors expressed in HEK293 cells (Tia et al., 1996). The majority of wild-type current deactivation followed a fast time course with a rate of $\sim 50 \mathrm{sec}^{-1}$, followed by a slower deactivation at $\sim 7 \sec ^{-1}$ (Table 1). As reported previously (Jones and Westbrook, 1995), the relative amount of fast deactivation in wild-type receptors decreased with longer GABA pulses. After 3 sec GABA application, the relative amplitude of the slow deactivation component increased to $60 \pm$ $5.1 \%(n=7)$, whereas the rates of fast and slow deactivation were unaffected by pulse duration.

Deactivation kinetics for both $\alpha_{1}$ (L264T) $\beta_{2} \gamma_{2 \mathrm{~L}}$ and $\alpha_{1}(\mathrm{~S} 270 \mathrm{I}) \beta_{2} \gamma_{2 \mathrm{~L}} \mathrm{GABA}_{\mathrm{A}}$ receptor currents displayed only single rates that were very slow compared with wild-type deactivation (Fig. 5, middle and right; Table 1). Deactivation of $\alpha_{1}(\mathrm{~L} 264 \mathrm{~T}) \beta_{2} \gamma_{2 \mathrm{~L}}$ currents proceeded at a rate of $\sim 1 \mathrm{sec}^{-1}$, over 


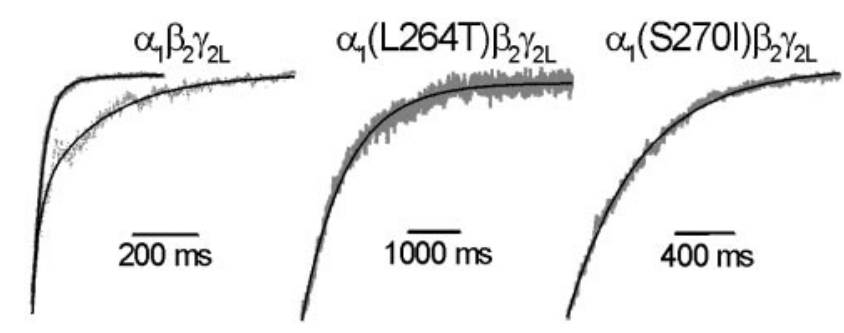

Figure 5. Deactivation kinetics of wild-type and mutant $\mathrm{GABA}_{\mathrm{A}}$ receptors. Examples of current decays (deactivation) recorded from voltageclamped membrane patches after removing GABA after pulses of saturating (1 mM) GABA. Exponential fits to deactivating current phases are shown overlaid on the currents. Left, Wild type $\left(\alpha_{1} \beta_{2} \gamma_{2 L}\right)$. Deactivation after a $10 \mathrm{msec}$ pulse of $1 \mathrm{~mm}$ GABA (solid trace) was best fitted by two exponential components with $\tau_{\text {fast }}^{-1}=35 \mathrm{sec}^{-1}(87 \%)$ and $\tau_{\text {slow }}^{-1}=6.5 \mathrm{sec}^{-1}$ $(13 \%)$. Deactivation after a $1000 \mathrm{msec}$ desensitizing pulse of $1 \mathrm{~mm}$ GABA (dotted trace) shows slower apparent deactivation. The data were best fitted by two exponential components with $\tau_{\text {fast }}^{-1}=45 \mathrm{sec}^{-1}(44 \%)$ and $\tau_{\text {slow }}^{-1}=5.3 \mathrm{sec}^{-1}(56 \%)$. Middle, $\alpha_{1}(\mathrm{~L} 264 \mathrm{~T}) \beta_{2} \gamma_{2}$. Deactivation after a 100 msec pulse of $1 \mathrm{~mm}$ GABA was best fitted by a single exponential with $\tau^{-1}=1.4 \mathrm{sec}^{-1}$. No significant change in deactivation rate was observed using a $5 \mathrm{sec}$ pulse of GABA. Right, $\alpha_{1}(\mathrm{~S} 270 \mathrm{I}) \beta_{2} \gamma_{2 \mathrm{~L}}$. Deactivation after a $10 \mathrm{msec}$ pulse of $1 \mathrm{~mm}$ GABA was best fitted by a single exponential with $\tau^{-1}=2.3 \mathrm{sec}^{-1}$. No significant change was observed using a $1 \mathrm{sec}$ pulse of GABA. Average deactivation parameters for all experiments are reported in Table 1.

40 times slower than the dominant deactivation rate in wild type. Deactivation of maximally activated $\alpha_{1}(\mathrm{~S} 270 \mathrm{I}) \beta_{2} \gamma_{2 \mathrm{~L}}$ currents was $\sim 17$-fold slower than wild-type fast deactivation $\left(\sim 3 \mathrm{sec}^{-1}\right)$. Furthermore, deactivation of mutant receptor currents did not change after prolonged exposure to GABA (desensitization).

\section{DISCUSSION}

We studied macrocurrent kinetics in $\mathrm{GABA}_{\mathrm{A}}$ receptors containing TM2 mutations that enhance apparent GABA sensitivity. Compared with wild type, both $\alpha_{1}$ (L264T) and $\alpha_{1}$ (S270I) mutations slow deactivation and induce increased spontaneous activation in the absence of GABA without changing apparent activation kinetics. One major difference between currents from the two mutant receptors was observed: $\alpha_{1}(\mathrm{~S} 270 \mathrm{I}) \beta_{2} \gamma_{2 \mathrm{~L}}$ receptors desensitized like wild type, whereas $\alpha_{1}(\mathrm{~L} 264 \mathrm{~T}) \beta_{2} \gamma_{2 \mathrm{~L}}$ receptors display very slow desensitization.

To help interpret and illustrate how these mutations alter $\mathrm{GABA}_{\mathrm{A}}$ receptor molecular transitions, we considered a simple, semiquantitative allosteric-kinetic model (Fig. 6A). The model consists of three types of states: resting closed (R), open (conducting; O), and desensitized (D), each of which can bind GABA (G). It incorporates known $\mathrm{GABA}_{\mathrm{A}}$ receptor state transitions, including gating from both ligand-bound and unliganded states (Chang and Weiss, 1999), and desensitization from both closed and open states (Burkat et al., 2001) but contains fewer states than other allosteric models (Hall, 2000; Pearce, 2001).

\section{Both $\alpha_{1}(\mathrm{~L} 264 \mathrm{~T})$ and $\alpha_{1}$ (S270l) mutations stabilize open states}

The many similar changes in equilibrium and kinetic behavior caused by $\alpha_{1}(\mathrm{~L} 264 \mathrm{~T})$ and $\alpha_{1}(\mathrm{~S} 270 \mathrm{I})$ mutations suggest that they affect a common molecular transition. Indeed, all of the common effects of these two mutations can be explained by slowing channel closing rates. The reduced $\mathrm{EC}_{50}$ values of the mutant receptors could be attributable to enhanced microscopic binding (reduced $K_{G} \equiv k_{\text {off }} / k_{\text {on }}$ ), gating efficacy (reduced $\Phi \equiv \alpha / \beta$ ), or both (Colquhoun, 1998). Our allosteric-kinetic model (Fig. 6A) illus- trates that reductions in either $K_{G}\left(k_{\text {off }}\right)$ or $\Phi(\alpha)$ result in reduced $\mathrm{EC}_{50}$ values, unaltered desensitization at high GABA, and slow deactivation (Fig. $6 C, D$ ). The only clearly distinguishing feature between currents generated by these two altered models is the amount of spontaneous activity they display in the absence of GABA, because increased activation in the absence of GABA is produced by increased gating efficacy but not by increased GABA binding affinity. Additional support for this interpretation comes from other studies reporting increased spontaneous gating by $\mathrm{GABA}_{\mathrm{A}}$ receptors containing either $\alpha(\mathrm{S} 270)$ or $\alpha(\mathrm{L} 264)$ mutations (Chang and Weiss, 1999; Findlay et al., 2000; Ueno et al., 2000).

Although both $\alpha_{1}(\mathrm{~L} 264 \mathrm{~T})$ and $\alpha_{1}(\mathrm{~S} 270 \mathrm{I})$ mutations produce qualitatively similar changes in $\mathrm{GABA}_{\mathrm{A}}$ receptor macrocurrent gating, the impact of $\alpha_{1}(\mathrm{~L} 264 \mathrm{~T})$ on spontaneous activation and $\mathrm{EC}_{50}$ is clearly larger than that of $\alpha_{1}(\mathrm{~S} 270 \mathrm{I})$. Importantly, the relative $\mathrm{EC}_{50}$ values and the amounts of spontaneous gating activity (Table 1) for these mutants are in very good accord with quantitative predictions for doubly liganded ion channels (Forman and Zhou, 1999) and the allosteric gating model proposed by Chang and Weiss (1999). The $\mathrm{EC}_{50}$ for doubly liganded ion channels is predicted to depend on the square root of the closing rate/opening rate ratio $(\alpha / \beta$; Forman and Zhou, 1999). Because gating probability in the absence of ligand is directly proportional to gating probability of ligand-bound receptors $[\beta /(\alpha+\beta)], \mathrm{EC}_{50}$ should also be proportional to the inverse square root of spontaneous activation probability (Chang and Weiss, 1999). Thus, if altered gating probability (efficacy) is the basis for our mutationinduced $\mathrm{EC}_{50}$ changes, the sevenfold ratio of $\mathrm{EC}_{50}$ values for $\alpha_{1}(\mathrm{~S} 270 \mathrm{I})$ and $\alpha_{1}(\mathrm{~L} 264 \mathrm{~T})$ mutants predicts that, compared with $\alpha_{1}(\mathrm{~S} 270 \mathrm{I}) \beta_{2} \gamma_{2 \mathrm{~L}}, \alpha_{1}(\mathrm{~L} 264 \mathrm{~T}) \beta_{2} \gamma_{2 \mathrm{~L}}$ should display $\sim 50$-fold more spontaneous gating. This agrees well with the $72 \pm 35$-fold ratio for the spontaneous activities of these two channels. The ratio of $\mathrm{EC}_{50}$ values for wild-type $\alpha_{1} \beta_{2} \gamma_{2 \mathrm{~L}}$ and $\alpha_{1}(\mathrm{~L} 264 \mathrm{~T}) \beta_{2} \gamma_{2 \mathrm{~L}}$ receptors is 83 , suggesting that gating efficacy is increased $\sim 7000$-fold by the mutation and predicting an open probability for unliganded wild-type receptors of $0.36 / 7000 \approx 5 \times 10^{-5}$. Again, this quantitatively agrees with our electrophysiologic measurements. A $\log -\log$ plot of $\mathrm{EC}_{50}$ versus the fraction of spontaneous activation for the three channels we studied displays the predicted slope of -0.5 (Fig. 7).

Enhanced gating by $\alpha_{1}(\mathrm{~L} 264 \mathrm{~T})$ and $\alpha_{1}(\mathrm{~S} 270 \mathrm{I})$ mutations could be attributable to slowed channel closing $(\alpha)$ or faster channel opening $(\beta)$. Current activation rates (Fig. 3) indicate that GABA binding rates $\left(k_{\mathrm{on}}\right)$ and channel opening rates $(\beta)$ are unaltered by the mutations. Thus, channel closing rates $\left(\alpha\right.$ and $\left.\alpha^{\prime}\right)$ must be reduced. Prolonged openings in single-channel studies of $\mathrm{nACh}$ and $\mathrm{GABA}_{\mathrm{A}}$ receptors containing L9'T/S mutations support our conclusion for $\alpha_{1}$ (L264T) (Filatov and White, 1995; Labarca et al., 1995; Bianchi and Macdonald, 2001). Prolonged openings have also been observed in single-channel studies of the $\alpha_{1}(\mathrm{~S} 270 \mathrm{I})$ mutation in rat $\mathrm{GABA}_{\mathrm{A}}$ receptors $(\mathrm{J}$. H. Steinbach and G. Akk, personal communication).

The mutations we studied might also alter microscopic agonist affinity. Although our activation rate data rule out an altered $k_{\text {on }}$, there is no reliable way to estimate $k_{\text {off }}$ for $\mathrm{GABA}_{\mathrm{A}}$ receptors. Indirect support for unaltered binding comes from single-channel studies of nACh receptors, in which a single open state dominates, and many TM2 mutations have been shown to alter gating but not binding (Grosman and Auerbach, 2000; Grosman et al., 2000). 
Figure 6. A simple allosteric-kinetic model of $\mathrm{GABA}_{\mathrm{A}}$ receptor states and transitions. $A$, A schematic incorporating three types of interchanging states: resting $(R)$, open $(O)$, and desensitized $(D)$. Each of these states can bind GABA $(G)$, forming states RG, OG, and DG. Only O and OG states are conducting and assumed to have equal conductance. The model incorporates allosteric gating of $\mathrm{GABA}_{\mathrm{A}}$ receptors (Chang and Weiss, 1999) by linking the gating of liganded and unliganded receptors (maintaining a fixed ratio between closing rates $\alpha$ and $\alpha^{\prime}$ ). In addition, the model allows desensitization from both closed and open states at equal rates $\left(k_{\mathrm{des}}\right)$ as shown by Burkat et al. (2001). The major states involved in binding, gating, and desensitization are highlighted in bold letters. Note that each state in the schematic is an element in one three-state cycle and two four-state cycles, resulting in highly constrained equilibrium behavior. For calculations of model-generated currents, the model was further constrained by making all three GABA binding rates $\left(k_{\text {on }}\right)$ equal. The "wildtype" kinetic model (18 rate constants) was fully defined by eight input rate values and the $\alpha^{\prime} / \alpha$ ratio: $k_{\text {on }}=10^{7} \mathrm{M}^{-1} \mathrm{sec}^{-1} ; k_{\text {off }}^{\mathrm{R}}=500 \mathrm{sec}^{-1}$; $\beta=3000 \mathrm{sec}^{-1} ; \alpha=200 \mathrm{sec}^{-1} ; k_{\mathrm{des}}=2 \mathrm{sec}^{-1} ; k_{\mathrm{res}}^{\mathrm{R}}$, $=200 \mathrm{sec}^{-1} ; k_{\mathrm{res}}^{\mathrm{OG}}=0.5 \mathrm{sec}^{-1} ; \beta^{\prime}=5 \mathrm{sec}^{-1}$; $\alpha^{\prime} / \alpha=5$. Other rate constants were calculated from constraints on the model. Rate constants
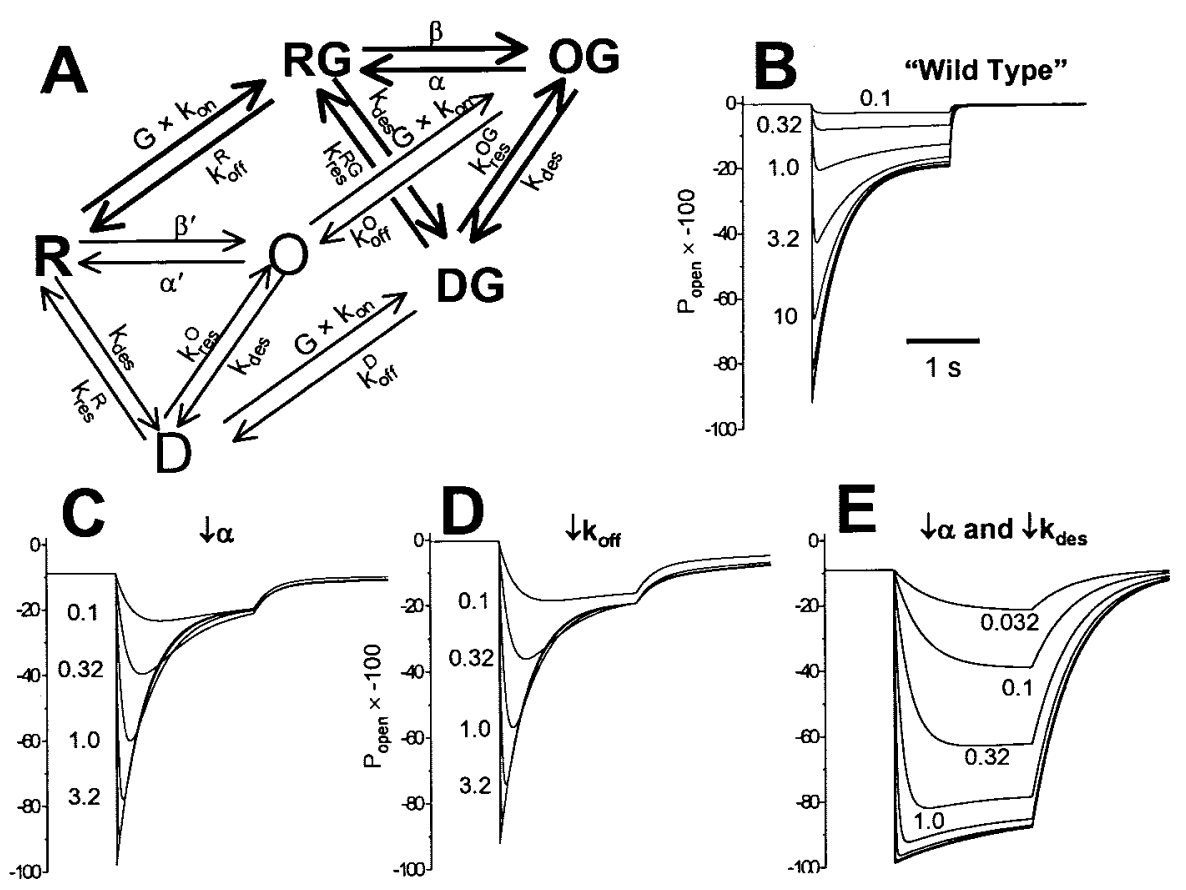

were not "fitted" to our experimental results, and some rate constants were assigned to enable display of multiple features of model-generated traces on a single time scale. $B-E$, Model-generated macrocurrent traces were calculated under conditions mimicking a 1 sec baseline $(0 \mathrm{GABA})$ period, a 2 sec GABA pulse (concentrations labeled in micromolar), and $2 \mathrm{sec}$ of deactivation at 0 GABA. $B$, Wild-type model-generated currents at various GABA concentrations display features qualitatively similar to experimental currents, including low activation at zero GABA $\left(P_{0}=0.005\right)$, fast activation, desensitization, and fast deactivation. $C$, Decreasing $\alpha 20$-fold does not alter the maximal rate of desensitization and slows the deactivation rate approximately sevenfold. There is increased activation at zero GABA $\left(P_{0}=0.091\right)$, and $\mathrm{EC}_{50}$ is reduced approximately fivefold. These changes qualitatively reflect those produced by the $\alpha_{1}(\mathrm{~S} 270 \mathrm{I})$ mutation. $D$, Decreasing $k_{\text {off }} 20$-fold does not alter the maximal rate of desensitization and slows the deactivation rate approximately sevenfold. Compared with wild type, activation at zero GABA is unchanged $\left(P_{0}=0.005\right)$, and $\mathrm{EC}_{50}$ is reduced approximately sevenfold. $E$, Decreasing both $\alpha$ and $k_{\text {des }} 20$-fold increases activation at zero GABA $\left(P_{0}=0.091\right)$ and reduces EC E0 $_{5} \sim 18$-fold. The apparent rate and extent of desensitization and the rate of deactivation are reduced. These changes qualitatively reflect those produced by the $\alpha_{1}(\mathrm{~L} 264 \mathrm{~T})$ mutation.

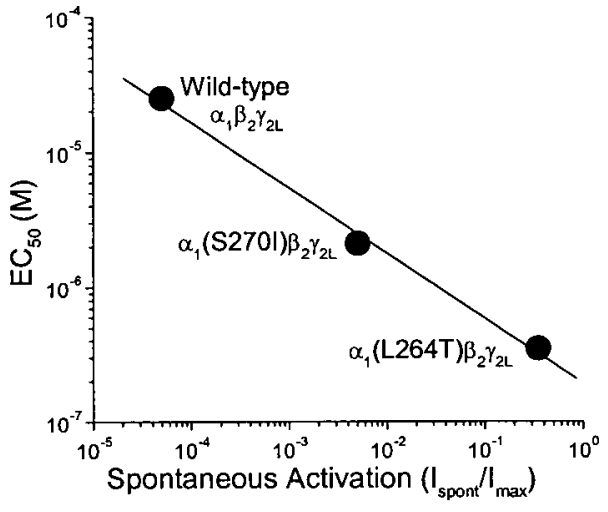

Figure 7. An allosteric gating mechanism is consistent with the relationship between GABA $\mathrm{EC}_{50}$ and spontaneous activation. A log-log plot of $\mathrm{EC}_{50}$ versus fraction of spontaneous activation (Table 1) for wild type and the two mutant receptors is fitted to a line with a slope of $-0.48 \pm 0.033$. A slope of -0.5 is predicted if the mutations equally increase receptor gating probability both in the absence of GABA and when both agonist sites are occupied. If GABA binding affinity was altered by the mutations, spontaneous activation is not predicted to change from the wild-type value.

\section{Altered gating without altered desensitization: the $\alpha_{1}$ (S270l) mutation}

Although $\alpha_{1}(\mathrm{~S} 270 \mathrm{I}) \beta_{2} \gamma_{2 \mathrm{~L}}$ currents display altered gating, their desensitization is indistinguishable from that of wild-type $\alpha_{1} \beta_{2} \gamma_{2 \mathrm{~L}}$ currents. In other words, the effects of this mutation on gating and desensitization appear uncoupled. Our allosteric- kinetic model demonstrates that reducing only closing rates produces changes in macrocurrents that are qualitatively similar to those induced by the $\alpha_{1}$ (S270I) mutation (Fig. 6C).

A number of kinetic models used to simulate the behavior of $\mathrm{GABA}_{\mathrm{A}}$ receptors, both simple and complex, has incorporated negative coupling between gating and desensitization, by allowing desensitization to proceed exclusively from closed states (Gingrich et al., 1995; Jones and Westbrook, 1995; Bai et al., 1999; Haas and Macdonald, 1999; Li and Pearce, 2000; Bianchi and Macdonald, 2001). Consequently, these models predict that shifting gating equilibrium toward open states reduces occupancy of closed states, slowing macroscopic desensitization. Bianchi and Macdonald (2001) used this type of scheme to explain the slow desensitization of $\alpha_{1} \beta_{3} \gamma_{2 \mathrm{~L}}$ (L9'S) currents. In contrast, desensitization in our allosteric-kinetic model proceeds from either closed or open states at similar rates (Burkat et al., 2001), explicitly uncoupling desensitization from gating.

When we attempted to model the gating and desensitization effects of the $\alpha_{1}$ (S270I) mutation with a negatively coupled mechanism, the reduced desensitization probability caused by increased gating efficacy required precise compensation by a second accelerating effect on the microscopic desensitization rate. This seems far less probable than the uncoupled gating and desensitization behavior illustrated by our model (Fig. 6C), particularly when considering that both the rates and extents of several desensitization pathways were unaltered by the $\alpha_{1}$ (S270I) mutation. Although negatively coupled models represent an extreme case in which the rate of desensitization from open states is zero, models in which open and closed states desensitize at different 
rates still predict that changing gating efficacy will alter apparent desensitization rates. Only if desensitization rates from closed and open states are similar can the open-closed equilibrium shift without altering the apparent desensitization rate. Thus, the uncoupling of gating and desensitization effects by the $\alpha_{1}(\mathrm{~S} 270 \mathrm{I})$ mutation supports the conclusion that open $\mathrm{GABA}_{\mathrm{A}}$ receptors can desensitize as rapidly as closed receptors.

The $\alpha_{1}(\mathrm{~S} 270 \mathrm{I})$ mutation stabilizes open states relative to resting states, without changing the relative stability of open and desensitized states. Thus, this mutation also shifts the equilibrium between resting and desensitized states toward desensitization. We observed this shift as the slowing of resensitization from GABA-induced desensitization.

\section{Altered gating coupled to altered desensitization: the $\alpha_{1}($ L264T) mutation}

In contrast to $\alpha_{1}(\mathrm{~S} 270 \mathrm{I}) \beta_{2} \gamma_{2 \mathrm{~L}}$ currents, those from $\alpha_{1}(\mathrm{~L} 264 \mathrm{~T}) \beta_{2} \gamma_{2 \mathrm{~L}}$ receptors display slowed GABA-induced desensitization. Their characteristics (Table 1 ) are very similar to those of $\alpha_{1} \beta_{3} \gamma_{2 \mathrm{~L}}$ (L9'S) $\mathrm{GABA}_{\mathrm{A}}$ receptors (Bianchi and Macdonald, 2001), demonstrating that $\mathrm{L} 9^{\prime} \mathrm{T} / \mathrm{S}$ mutations on $\alpha$ and $\gamma$ subunits produce similar changes in molecular dynamics (Chang et al., 1996; Chang and Weiss, 1999).

The characteristics of $\alpha_{1}(\mathrm{~L} 264 \mathrm{~T}) \beta_{2} \gamma_{2 \mathrm{~L}}$ currents in this study are consistent with selective stabilization of open states relative to both closed and desensitized states. In the context of our allosteric-kinetic model (Fig. $6 A$ ), this implies that both closing rates $\left(\alpha, \alpha^{\prime}\right)$ and desensitization rates $\left(k_{\mathrm{des}}\right)$ are reduced by equivalent factors. When our kinetic model is altered in this fashion, its generated currents display features like those of $\alpha_{1}(\mathrm{~L} 264 \mathrm{~T}) \beta_{2} \gamma_{2 \mathrm{~L}}$ currents (Fig. $6 E$ ). Compared with Figure $6 C$, the same reduced $\alpha$ in Figure $6 E$ results in a larger (3.5-fold) drop in $\mathrm{EC}_{50}$. This difference is attributable to the different desensitization rates in the two models; in Figure $6 C$, but not $6 E$, desensitization truncates current activation at low GABA, resulting in lower peak currents and a higher $\mathrm{EC}_{50}$. An additional consequence of slowed desensitization is that current activation at low GABA appears slower. Indeed, the model qualitatively reflects our results; of the receptors we studied, $\alpha_{1}(\mathrm{~L} 264 \mathrm{~T}) \beta_{2} \gamma_{2 \mathrm{~L}}$ currents displayed the slowest activation at low GABA.

\section{Desensitization-deactivation coupling}

An intriguing feature of our results is that desensitization of the mutant currents does not prolong deactivation, as observed in wild-type currents. Although it is tempting to speculate that the loss of gating-desensitization coupling in $\alpha_{1}(\mathrm{~S} 270 \mathrm{I}) \beta_{2} \gamma_{2 \mathrm{~L}}$ currents also removes desensitization-deactivation coupling, the $\alpha_{1}(\mathrm{~L} 264 \mathrm{~T}) \beta_{2} \gamma_{2 \mathrm{~L}}$ currents represent a counter example: gatingdesensitization coupling appears present, but desensitizationdeactivation coupling is absent. Our allosteric-kinetic model (Fig. 6A) suggests an explanation for these observations. Desensitization-deactivation coupling is contingent on two quantitative features of the model. First, reopening from desensitized states, as reported by Jones and Westbrook (1995), implies that resensitization from DG via either RG or OG is faster than silent resensitization via agonist dissociation (DG to D). Second, resensitization must also be slower than deactivation from the dominant conducting state, OG via channel closure (RG). Thus, for wild-type receptors, $\alpha>k_{\text {res }}^{\mathrm{OG}}>k_{\mathrm{off}}^{\mathrm{D}}$ and the slow phase of deactivation after desensitization displays a rate close to $k_{\mathrm{res}}^{\mathrm{OG}}$, the rate-limiting step in the path from $\mathrm{DG} \rightarrow \mathrm{OG} \leftrightarrow \mathrm{RG} \rightarrow \mathrm{R}$. We postulate that, in $\alpha_{1}(\mathrm{~S} 270 \mathrm{I}) \beta_{2} \gamma_{2 \mathrm{~L}}$ and $\alpha_{1}(\mathrm{~L} 264 \mathrm{~T}) \beta_{2} \gamma_{2 \mathrm{~L}}$ receptors, this second condition is lost, because channel closure becomes slower than resensitization. When $k_{\text {res }}^{\mathrm{OG}}>k_{\text {off }}^{\mathrm{R}}>\alpha$, channel closure becomes the rate-limiting step in deactivation from both open and desensitized states. The allosteric-kinetic model can display this type of behavior if desensitization and resensitization rates are increased or if $\alpha$ is reduced sufficiently (data not shown).

\section{TM2 in gating and desensitization}

Auerbach and Akk (1998) suggested that conductance gating and desensitization of $\mathrm{nACh}$ receptors represent conformational changes of distinct but coupled gates. Our results in $\mathrm{GABA}_{\mathrm{A}}$ receptors are consistent with a two-gate model, each linked to different parts of the TM2 domain.

Like previous studies (Revah et al., 1991; Bianchi and Macdonald, 2001), our results indicate that L9'T/S mutations influence both gating and desensitization by selectively stabilizing the open state. How this occurs is suggested by chemical modification of cysteine at $9^{\prime}$, which is $\leq 10,000$-fold faster in activated than in closed or slowly desensitized nACh receptors (Pascual and Karlin, 1998; Wilson and Karlin, 2001). Thus, during gating, the 9' residues likely move from buried positions to water exposed in the open channel, becoming buried again during desensitization or closing. The estimated free energy difference for burial of a water-exposed leucine versus serine/threonine side chain is -2.7 to $-1.8 \mathrm{kcal} / \mathrm{mol}$ (Karplus, 1997). With two $\alpha$ subunits per $\mathrm{GABA}_{\mathrm{A}}$ receptor, this can account for the estimated 6500 -fold increase in open state stability $(-5.2 \mathrm{kcal} / \mathrm{mol})$ associated with $\alpha_{1}(\mathrm{~L} 264 \mathrm{~T} / \mathrm{S})$ mutations.

Thus, the $9^{\prime}$ leucines may contribute to gating-desensitization coupling, although it remains unclear whether such coupling occurs in wild-type $\mathrm{GABA}_{\mathrm{A}}$ receptors as well as mutants. Others have postulated that $9^{\prime}$ leucines may act as a conductance gate (Unwin, 1995). However, the 9' leucines cannot both be the conductance gate and contribute to gating-desensitization coupling, because if conductance gate structures are energetically linked to desensitization, then gating and desensitization must always be coupled, which would conflict with our $\alpha_{1}(\mathrm{~S} 270 \mathrm{I})$ results.

Few studies have investigated the role of TM2 in rapid desensitization of $\mathrm{GABA}_{\mathrm{A}}$ receptors and related ion channels. Wilson and Karlin (2001) investigated accessibility of $\mathrm{nACh}$ receptor TM2 cysteines after slow (minutes time scale) desensitization, a process distinct from rapid desensitization. We reported both $\mathrm{EC}_{50}$ and rapid desensitization rates for a series of $\alpha$ subunit TM2 mutations in $\mathrm{nACh}$ receptors (Zhou et al., 2000). Of 13 residues studied, mutations at eight changed $\mathrm{EC}_{50}$ over fivefold from wild type, presumably by altering gating efficacy. Together with our current results, these data suggest that residues distributed throughout TM2 are involved in gating, which might be expected if gating involves movement of the entire domain (Grosman et al., 2000; Horenstein et al., 2001). In contrast, rapid desensitization of $\mathrm{nACh}$ receptors was influenced only by a subset of four TM2 mutations that altered gating, extending from the middle $\left(9^{\prime}\right)$ of the domain toward its outer end. Rapid desensitization may thus involve rearrangement of the outer end of TM2, without movement of the cytoplasmic end, which has been proposed to form the conductance gate (Wilson and Karlin, 1998). Alternatively, rapid desensitization may involve movement of other structures, such as the outer end of TM1 or portions of the N-terminal domain, that interact with the outer half of TM2 (Bianchi et al., 2001). 


\section{REFERENCES}

Auerbach A, Akk G (1998) Desensitization of mouse nicotinic acetylcholine receptor channels. A two-gate mechanism. J Gen Physiol 112:181-197.

Bai D, Pennefather PS, MacDonald JF, Orser BA (1999) The general anesthetic propofol slows deactivation and desensitization of $\mathrm{GABA}_{\mathrm{A}}$ receptors. J Neurosci 19:10635-10646.

Barnard EA, Skolnick P, Olsen RW, Mohler H, Sieghart W, Biggio G, Braestrup C, Bateson AN, Langer SZ (1998) International Union of Pharmacology. XV. Subtypes of gamma-aminobutyric acidA receptors: classification on the basis of subunit structure and receptor function. Pharmacol Rev 50:291-313.

Bianchi MT, Macdonald RL (2001) Mutation of the 9' leucine in the GABA-A receptor gamma-2L subunit produces an apparent decrease in desensitization by stabilizing open states without altering desensitized states. Neuropharmacology 41:737-744.

Bianchi MT, Haas KF, Macdonald RL (2001) Structural determinants of fast desensitization and desensitization-deactivation coupling in GABA $_{\mathrm{A}}$ receptors. J Neurosci 21:1127-1136.

Boileau AJ, Czajkowski C (1999) Identification of transduction elements for benzodiazepine modulation of the $\mathrm{GABA}_{\mathrm{A}}$ receptor: three residues are required for allosteric coupling. J Neurosci 19:10213-10220.

Burkat PM, Yang J, Gingrich K (2001) Dominant gating governing transient $\mathrm{GABA}_{\mathrm{A}}$ receptor activity: a first latency and $P_{\mathrm{o} / \mathrm{o}}$ analysis. J Neurosci 21:7026-7036.

Celentano JJ, Wong RKS (1994) Multiphasic desensitization of the $\mathrm{GABA}_{\mathrm{A}}$ receptor in outside out patches. Biophys J 66:1039-1050.

Chang Y, Weiss DS (1998) Substitutions of the highly conserved M2 leucine create spontaneously opening rho1 gamma-aminobutyric acid receptors. Mol Pharmacol 53:511-523.

Chang Y, Weiss DS (1999) Allosteric activation mechanism of the alpha1beta2gamma2 gamma-aminobutyric acid type A receptor revealed by mutation of the conserved M2 leucine. Biophys J 77:2542-2551.

Chang Y, Wang R, Barot S, Weiss DS (1996) Stoichiometry of a recombinant GABA receptor. J Neurosci 16:5415-5424.

Chen C, Okayama H (1987) High efficiency transformation of mammalian cells by plasmid DNA. Mol Cell Biol 7:2745-2752.

Colquhoun D (1998) Binding, gating, affinity, and efficacy: the interpretation of structure-activity relationships for agonists and of the effects of mutating receptors. Br J Pharmacol 125:924-947.

Colquhoun D, Hawkes AG (1995) A Q-matrix cookbook: how to write only one program to calculate the single-channel and macroscopic predictions for any kinetic mechanism. In: Single-channel recording (Sakmann B, Neher E, eds), pp 589-633. New York: Plenum.

Dalziel JE, Cox GB, Gage PW, Birnir B (2000) Mutating the highly conserved second membrane-spanning region 9' leucine residue in the $\alpha 1$ or $\beta 1$ subunit produces subunit-specific changes in the function of human $\alpha 1 \beta 1$ GABA-A receptors. Mol Pharmacol 57:875-882.

Filatov GN, White MM (1995) The role of conserved leucines in the M2 domain of the acetylcholine receptor in channel gating. Mol Pharmacol 48:379-384.

Findlay GS, Ueno S, Harrison NL, Harris RA (2000) Allosteric modulation in spontaneously active mutant gamma-aminobutyric acid(A) receptors in frogs. Neurosci Lett 293:155-158.

Forman SA (1999) A hydrophobic photolabel inhibits nicotinic acetylcholine receptors via open-channel block following a slow step. Biochemistry 38:14559-14564.

Forman SA, Z hou Q (1999) Novel modulation of a nicotinic receptor channel mutant reveals that the open state is stabilized by ethanol. Mol Pharmacol 55:102-108.

Galzi JL, Changeux JP (1994) Neurotransmitter-gated ion channels as unconventional allosteric proteins. Curr Opin Struct Biol 4:554-565.

Gingrich KJ, Roberts WA, Kass RS (1995) Dependence of the GABA-A receptor gating kinetics on the alpha-subunit isoform: implications for structure-function relations and synaptic transmission. J Physiol (Lond) 489:529-543.

Grosman C, Auerbach A (2000) Asymmetric and independent contribution of the second transmembrane segment $12^{\prime}$ residues to diliganded gating of acetylcholine receptor channels: a single-channel study with choline as the agonist. J Gen Physiol 115:637-651.

Grosman C, Zhou M, Auerbach A (2000) Mapping the conformational wave of acetylcholine receptor channel gating. Nature 403:773-776.

Gurley D, Amin J, Ross PC, Weiss DS, White G (1995) Point mutations in the $\mathrm{M} 2$ region of the alpha, beta, or gamma subunit of the GABAA channel that abolish block by picrotoxin. Receptors Channels 3:13-20.

Haas KF, Macdonald RL (1999) GABAA receptor subunit gamma2 and delta subtypes confer unique kinetic properties on recombinant GABAA receptor currents in mouse fibroblasts. J Physiol (Lond) $514: 27-45$

Hadingham KL, Harkness PC, McKernan RM, Quirk K, Le Bourdelles B, Horne AL, Kemp JA, Barnard EA, Ragan CI, Whiting PJ (1992) Stable expression of mammalian type A gamma-aminobutyric acid receptors in mouse cells: demonstration of functional assembly of benzodiazepine-responsive sites. Proc Natl Acad Sci USA 89:6378-6382.
Hall DA (2000) Modeling the functional effects of allosteric modulators at pharmacological receptors: an extension of the two-state model of receptor activation. Mol Pharmacol 58:1412-1423.

Horenstein J, Wagner DA, Czajkowski C, Akabas MH (2001) Protein mobility and GABA-induced conformational changes in GABA(A) receptor pore-lining M2 segment. Nat Neurosci 4:477-485.

Jackson MB, Imoto K, Mishina M, Konno T, Numa S, Sakmann B (1990) Spontaneous and agonist-induced openings of an acetylcholine receptor channel composed of bovine muscle alpha-, beta- and deltasubunits. Pflügers Arch 417:129-135.

Jones MV, Westbrook GL (1995) Desensitized states prolong GABA-A channel responses to brief agonist pulses. Neuron 15:181-191.

Jurman ME, Boland LM, Liu Y, Yellen G (1994) Visual identification of individual transfected cells for electrophysiology using antibody-coated beads. Biotechniques 17:876-881.

Karlin A, Akabas MH (1995) Toward a structural basis for the function of nicotinic acetylcholine receptors and their cousins. Neuron $15: 1231-1244$

Karplus PA (1997) Hydrophobicity regained. Protein Science 6:1302-1307.

Koltchine VV, Finn SE, Jenkins A, Nikolaeva N, Lin A, Harrison NL (1999) Agonist gating and isoflurane potentiation in the human gamma-aminobutyric acid type A receptor determined by the volume of a second transmembrane domain residue. Mol Pharmacol 56:1087-1093.

Krampfl K, Lepier A, Jahn K, Franke C, Bufler J (1998) Molecular modulation of recombinant rat alpha1beta2gamma2 GABA(A) receptor channels by diazepam. Neurosci Lett 256:143-146.

Labarca C, Nowak MW, Zhang H, Tang L, Deshpande P, Lester HA (1995) Channel gating governed symmetrically by conserved leucine residues in the M2 domain of nicotinic receptors. Nature 376:514-516.

Li X, Pearce RA (2000) Effects of halothane on $\mathrm{GABA}_{\mathrm{A}}$ receptor kinetics: evidence for slowed agonist unbinding. J Neurosci 20:899-907.

Maconochie DJ, Zempel JM, Steinbach JH (1994) How quickly can GABAA receptors open? Neuron 12:61-71.

Mihic SJ, Ye Q, Wick MJ, Koltchine VV, Krasowski MD, Finn SE, Mascia MP, Valenzuela CF, Hanson KK, Greenblatt EP, Harris RA, Harrison NL (1997) Sites of alcohol and volatile anaesthetic action on GABA(A) and glycine receptors. Nature 389:385-389.

Neubig RR, Boyd ND, Cohen JB (1982) Conformations of torpedo acetylcholine receptor associated with ion transport and desensitization. Biochemistry 21:3460-3467.

Ortells MO, Lunt GG (1995) Evolutionary history of the ligand-gated ion-channel superfamily of receptors. Trends Neurosci 18:121-127.

Overstreet LS, Jones MV, Westbrook GL (2000) Slow desensitization regulates the availability of synaptic $\mathrm{GABA}_{\mathrm{A}}$ receptors. J Neurosci 20:7914-7921.

Pascual JM, Karlin A (1998) State-dependent accessibility and electrostatic potential in the channel of the acetylcholine receptor. Inferences from rates of reaction of thiosulfonates with substituted cysteines in the M2 segment of the alpha subunit. J Gen Physiol 111:717-739.

Pearce RA (2001) The binary elements model: an allosteric model of drug action incorporating multiple binding sites and multiple gates. Anesthesiology 95:A120.

Pritchett DB, Sontheimer H, Shivers BD, Ymer S, Kettenmann H, Schofield PR, Seeburg PH (1989) Importance of a novel GABAA receptor subunit for benzodiazepine pharmacology. Nature 338:582-585.

Revah F, Bertrand D, Galzi JL, Devillers-Thiery A, Mulle C, Hussy N, Bertrand S, Ballivet M, Changeux JP (1991) Mutations in the channel domain alter desensitization of a neuronal nicotinic receptor. Nature 353:846-849.

Scheller M, Forman SA (2001) Butanol effects on gamma-aminobutyric acid concentration-responses in human alpha-1beta-2gamma-2L GABA receptors with a mutation at alpha-1 S270. Neurosci Lett 297:179-182.

Tia S, Wang JF, Kotchabhakdi N, Vicini S (1996) Distinct deactivation and desensitization kinetics of recombinant GABAA receptors. Neuropharmacology 35:1375-1382.

Tierney ML, Birnir B, Pillai NP, Clements JD, Howitt SM, Cox GB, Gage PW (1996) Effects of mutating leucine to threonine in the M2 segment of alpha1 and beta1 subunits of GABAA alpha1beta1 receptors. J Membr Biol 154:11-21.

Ueno S, Zorumski C, Bracamontes J, Steinbach JH (1996) Endogenous subunits can cause ambiguities in the pharmacology of exogenous gamma-aminobutyric acidA receptors expressed in human embryonic kidney 293 cells. Mol Pharmacol 50:931-938.

Ueno S, Wick MJ, Ye Q, Harrison NL, Harris RA (1999) Subunit mutations affect ethanol actions on GABA(A) receptors expressed in Xenopus oocytes. Br J Pharmacol 127:377-382.

Ueno S, Lin A, Nikolaeva N, Trudell JR, Mihic SJ, Harris RA, Harrison NL (2000) Tryptophan scanning mutagenesis in TM2 of the GABA(A) receptor alpha subunit: effects on channel gating and regulation by ethanol. Br J Pharmacol 131:296-302.

Unwin N (1995) Acetylcholine receptor channel imaged in the open state. Nature 373:37-43. 
Verdoorn TA, Draguhn A, Ymer S, Seeburg PH, Sakmann B (1990) Functional properties of recombinant rat GABAA receptors depend upon subunit composition. Neuron 4:919-928.

Wilson GG, Karlin A (1998) The location of the gate in the acetylcholine receptor channel. Neuron 20:1269-1281.

Wilson GG, Karlin A (2001) Acetylcholine receptor channel structure in the resting, open, and desensitized states probed with the substituted-cysteine-accessibility method. Proc Natl Acad Sci USA 98:1241-1248.
Xu M, Akabas MH (1996) Identification of channel-lining residues in the M2 membrane-spanning segment of the GABA(A) receptor alpha1 subunit. J Gen Physiol 107:195-205.

Yakel JL, Lagrutta A, Adelman JP, North RA (1993) Single amino acid substitution affects desensitization of the 5-hydroxytryptamine type 3 receptor expressed in Xenopus oocytes. Proc Natl Acad Sci USA 90:5030-5033.

Zhou QL, Zhou Q, Forman SA (2000) The n-alcohol site in the nicotinic receptor pore is a hydrophobic patch. Biochemistry 39:14920-14926. 